\title{
Notes on spiders of the family Salticidae.
}

\section{The genera Spartaeus, Mintonia and Taraxetla}

\section{F. R. Wanless}

Department of Zoology, British Museum.(Natural History), CromwelliRoad London SWF SBD

\section{Synopsis}

The genus Taraxella is redefined to include those spartaeines in which the embolus of the male palp is largely obscured by tegular apophyses. The male of Spartaeus thailandica Wanless and the female of Mintonia melinauensis Wanless are described for the first time. One new species of Spartaeus, two new species of Mintonia and four new species of Taraxella are described from the Oriental Region. Diagnoses and figures are provided. The presence of mytiliform organs on the legs and filamentous metatarsal leg fringes are described for the first time. They are illustrated, together with femoral organs, muscle attachment sites and apophyses by scanning electron micrographs.

\section{Introduction}

The purpose of the present paper is to describe seven new species and the previously unknown male and female of two described species belonging in the subfamily Spartaeinae. The subfamily is of particular interest because some species spin large webs that are used to capture prey. Typical salticids are cursorial hunters with good vision that do not spin webs to capture prey, although they will spin silk nests in which to lay eggs, moult and sometimes mate, and generally rest at night or during other periods of inactivity (Jackson, 1979).

The first reports of web-spinning in jumping spiders (Coleman, 1978, 1980; Murphy, in Wanless, $1978 b$ ) were followed by several important studies (Jackson \& Blest, 1982; Jackson, 1982; Jackson \& Hallas, in press a) that confirmed the phenomenon and provided a rare insight into the biology of a small group of tropical salticids. These spiders all belonged in the old world genus, Portia Karsch, that is presently classified along with 12 other genera in the subfamily Spartaeinae. In addition to building large prey-capture webs, Portia species will leave their web and stalk prey as cursorial hunters i.e. in the same manner as other salticids. Furthermore, they may invade the webs of other spiders and feed on trapped insects (kleptoparasitism), the resident spider, or even its eggs (oophagy). In life they resemble tatty mouldy leaves or detritus, their ornate hair tufts and fringes (Fig. 3) providing a form of camouflage that enables them to stalk prey without being noticed, an important guise since they show a marked preference for other spiders, including salticids. Portia species are also 'aggressive vibratory mimics' for when they invade other spider webs they pluck the threads and deceive the owner into accepting Portia as potential prey only to be attacked themselves on approaching within jumping distance.

Occurrence of the unusual behaviour patterns of Portia species correlate to some degree in this and related spartaeines by the presence of morphological structures that are not known to occur in other spiders. These include femoral organs (Figs 5E; 14A) and pore-bearing apophyses (Figs 9E arrowed; 20A, B) both of which are especially evident in some of the species described below. Also present on the legs of one species (Spartaeus wildtrackii sp. n.) are mytiliform organs (Fig. 15A-C; $16 \mathrm{~A}, \mathrm{~B}$ ), structures that have hitherto only been found grouped together as a discrete patch on the dorsal surface of the abdomen (Fig. 20C) of species of Cyrba Simon, Portia, Gelotia Thorell, and Mintonia Wanless. The function of these structures is unknown but previous studies (Wanless, $1984 \mathrm{a}, \mathrm{b} ; 1985$ ) have suggested that they may be associated with pheromone dispersal. Jackson \& Hallas (in press $b$ ) have demonstrated that sex pheromones are involved in mate recognition in some Portia, Brettus Thorell and Cyrba, thus supporting earlier work by Legendre and Llinares, 

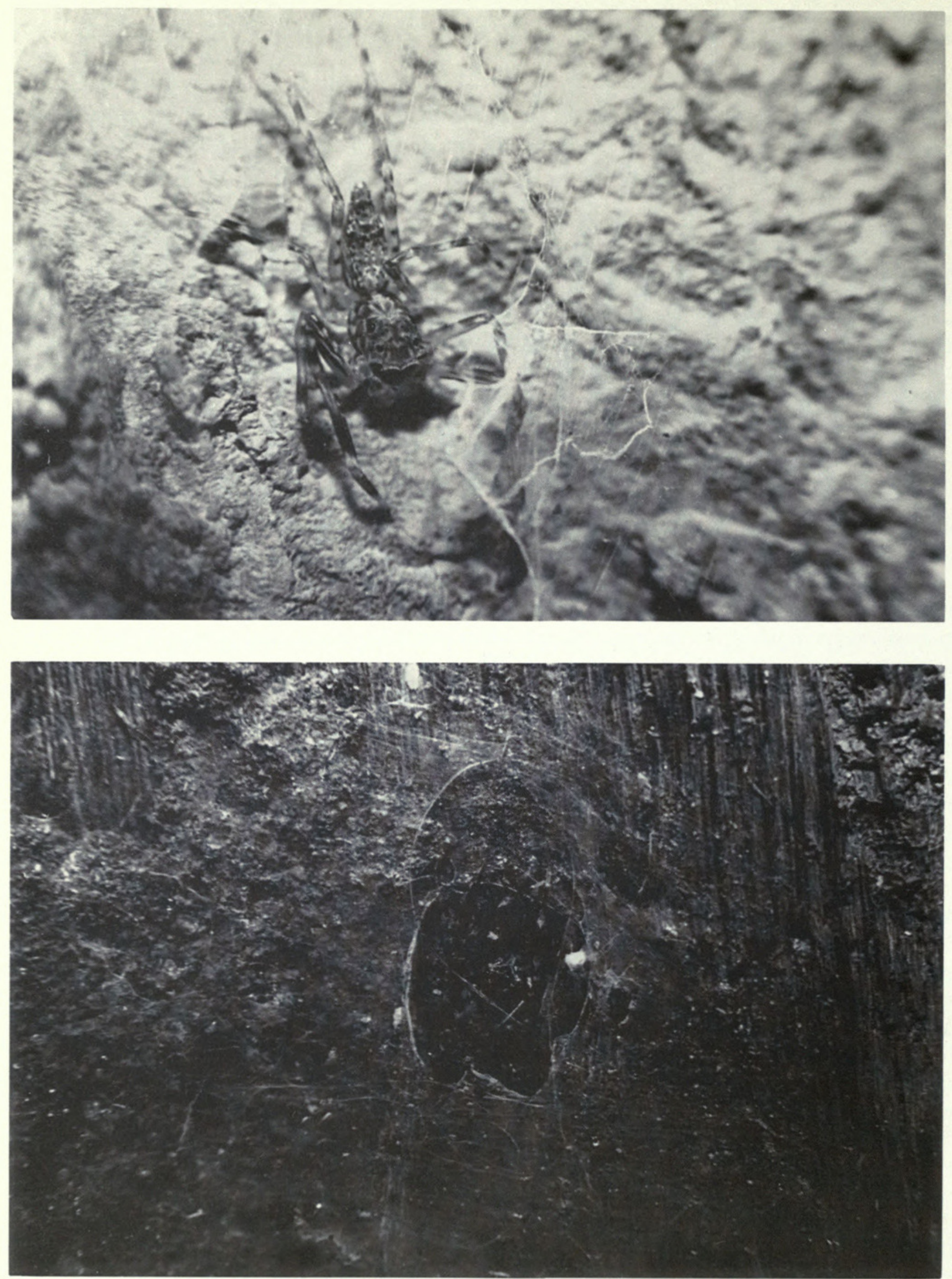

Fig. 1. (above) Spartaeus wildtrackii sp. n. Subadult $\hat{\sigma}$, under web on surface of tree trunk. Fig. 2 (below) web of Spartaeus wildtrackii sp. $\mathrm{n}$. 


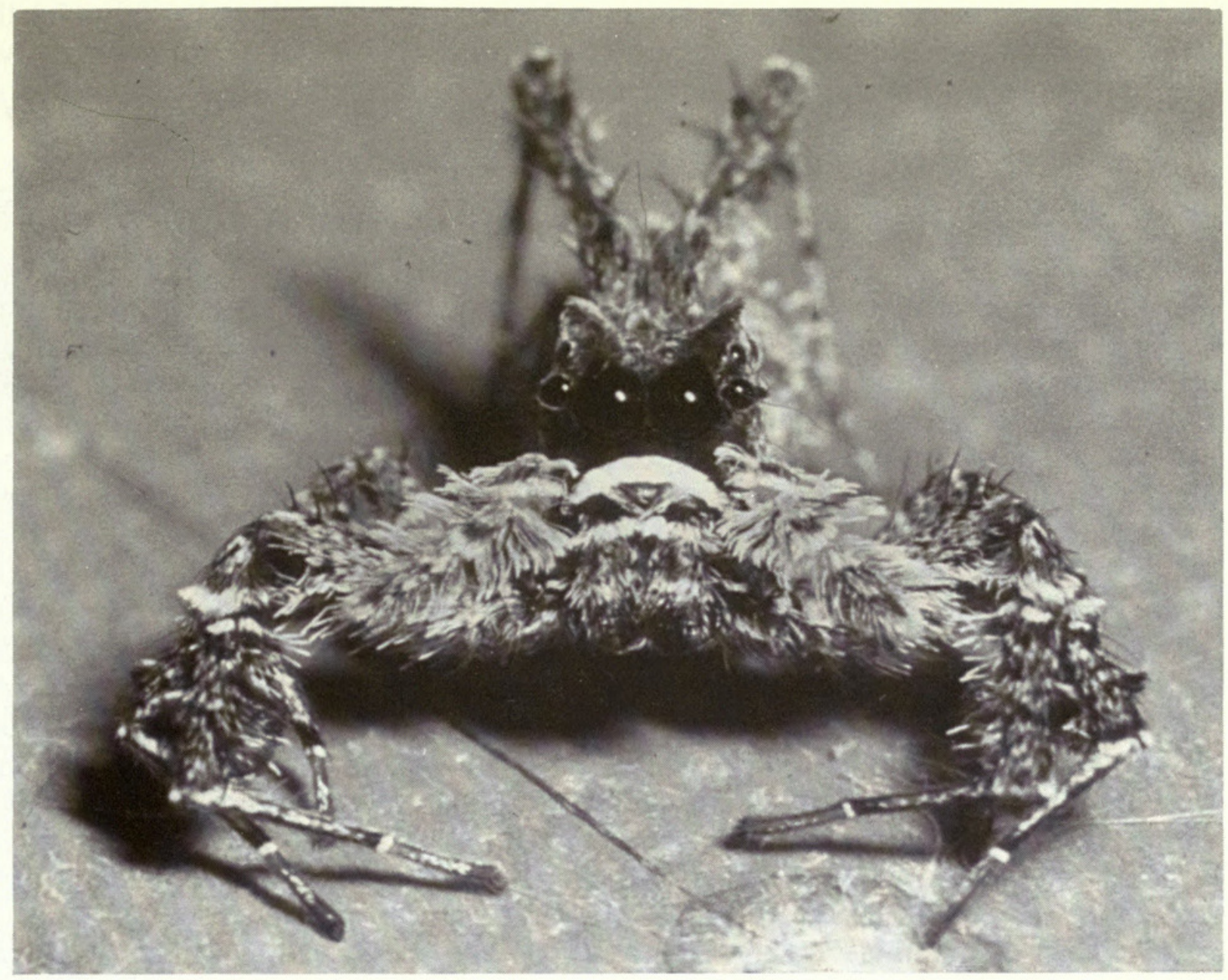

Fig. 3. Portia labiata (Thorell), $q$ from Malaysia.

1970 who noted that in Cyrba algerina (Lucas) pheromones left by the female stimulate the male and elicit searching behaviour.

Another feature clearly demonstrated by some of the species described below is the disparity in size of the posterior median eyes. In most spartaeines and also in a few other subfamilies the posterior median eyes are relatively large (Fig. 5A, B) and fully functional, whereas in most jumping spiders they are relatively small (Fig. 10A, B) with no demonstrable function. It is therefore of interest to note that in the species of Taraxella Wanless, described below there is a clear trend towards the development of small posterior median eyes. In practice the distinction between relatively large or relatively small becomes somewhat blurred in Taraxella, although there has hitherto been no difficulty in assigning one state or the other.

The presence of large posterior median eyes and web spinning behaviour in Portia species gave rise to the hypothesis (Jackson \& Blest, 1982) that the ancestors of modern day salticids evolved from web building spiders with poorly developed vision and that acute vision, evolved originally in a spider like Portia that became an araneophagic predator, proficient at invading diverse types of webs. Subsequent papers on morphology (Wanless, 1984a, $b$ ) the evolution of salticid eyes (Blest, 1984; Blest \& Sigmund, 1985) and behaviour (Jackson, 1985b; Jackson \& Hallas, in press $a, b$ ) have given support to the hypothesis and suggest that although spartaeine salticids are highly specialized they may nevertheless represent one of the most primitive branches of the family.

Studies, however, are at an early stage for the biology of tropical salticids is very poorly known, in fact the majority of species cannot even be identified with confidence. Also, it is important to appreciate that the subfamily Spartaeinae, with more than 60 described species, represents less than $1 \cdot 5 \%$ of the worlds salticid fauna. Despite this there are indications that jumping spiders make far more use of silk than has hitherto been supposed, for recent studies on other salticid groups have revealed species that build large prey-capture webs (Jackson, 1985a) and even species that live in groups forming nest complexes within the webs of other spiders (Jackson, in press). 
The standard abbreviations and measurements are those made by Wanless (1978) but for the leg spination the system adopted is that used by Platnick \& Shadab (1975). Note also, that the covering hairs on the male palps are not shown in any of the figures, because they are usually rather dense and obscure details.

\section{Genus SPARTAEUS Thorell}

Spartaeus: Wanless 1984a: 147 [synonymy, definition and species descriptions]. Blest \& Sigmund, $1985: 129$. Blest, 1985: 96.

Spartaeus is a small oriental genus comprising three species, S. spinimanus Thorell, from Indonesia, Malaysia and Sri Lanka, S. thailandicus Wanless from Thailand and $S$. wildtrackii sp. n., from Malaysia. They are easily distinguished by the structure of the genitalia.

All three species possess relatively large posterior median eyes (Fig. 4A), unusually long slender legs bearing numerous spines, and well developed femoral organs (Fig. 4E; 5E; 14A-C) on the first pair of legs of adult males. Also present on the legs of both males and females are disc-like mytiliform organs (Figs 15C; 16B). Those on the femora are more or less rounded and sparsely distributed (Fig. 16A), whereas those on the tibiae are ovoid and located distally on the dorsal surface of the segment (Fig. 15A, B). As mentioned above, mytiliform organs have hitherto only been found in the form of a patch on the dorsal surface of the abdomen. Their occurrence on legs is therefore of particular interest, especially as some are grouped on the distal end of the tibiae, an arrangement that may be unique to Spartaeus. However, at present these structures cannot be used to determine relationships as their distribution on the legs of other salticids is unknown. Furthermore, they are almost certainly homologous with pustuliform organs (see Hill, 1977 and Wanless, 1984) that occur as scattered pore-bearing pustules on the abdomen, legs and pedipalps of Icius Simon, Metaphidippus F.O.P-C and Phidippus Koch, and as a group on the abdomen of Holcolaetis Simon and Sonoita Peckham and Peckham.

The dorsal surface of the tibiae are characterised by hinge lines or rows of muscle attachment sites (Fig. 15A, B) that are electron dense and smooth in contrast to the surrounding cuticle. They resemble mytiliform organs, but lack pores and raised rims. It is also worth noting that they differ from the rows of triangular muscle attachment sites found on the tibiae and other leg segments of Holcolaetis species (see Wanless, 1985).

The biology of Spartaeus is unknown except for observations (see below) made by Mr P. D. Hillyard (BMNH) who also provided the photographs (Fig. 1;2) showing $S$. wildtrackii beneath its sheet web on a tree trunk.

\section{Spartaeus thailandicus Wanless}

(Fig. 4A-I)

Spartaeus thailandica Wanless, 1984a: 151. Holotype + , Thailand, BMNH, [examined].

DiagnOSIS. $S$. thailandicus seems to be most closely related to $S$. wildtrackii $\mathrm{sp}$. n., but may be distinguished by the presence of a tegular apophysis (Fig. 4G, arrow) and the form of the retrolateral tibial apophysis (Fig. 4F) in males; females are separated by the absence of a postepigynal furrow (see Wanless 1984a, Fig. 5D).

MALE, in good condition, from Khas Yai National Park, Thailand. Carapace (Fig. 4A-D): weakly iridescent under some angles of illumination; orange-brown lightly tinged and mottled black with a broad tapering pale yellow band on thoracic part; rubbed except for some black and pale amber hairs on sides. Eyes: laterals with black surrounds; fringed by white hairs. Clypeus: yellow-brown with sooty markings; sparsely clothed in black and whitish hairs. Chelicerae: long robust and diverging; posterior surface with series of transverse furrows; orange-brown lightly tinged black; sparsely clothed in black hairs with dense promarginal scopula; fang robust and curved; fang groove with eight promarginal teeth and 12 retromarginal denticles. Maxillae and labium: pale brownish yellow faintly tinged with some black. Sternum (Fig. 4B): pale yellow-brown with darker margins. Coxae: pale yellow-brown except for blackish sides of I and II. Abdomen: pale yellowbrown with black markings, ventrally a broad sooty band from epigastric furrow to spinnerets; 

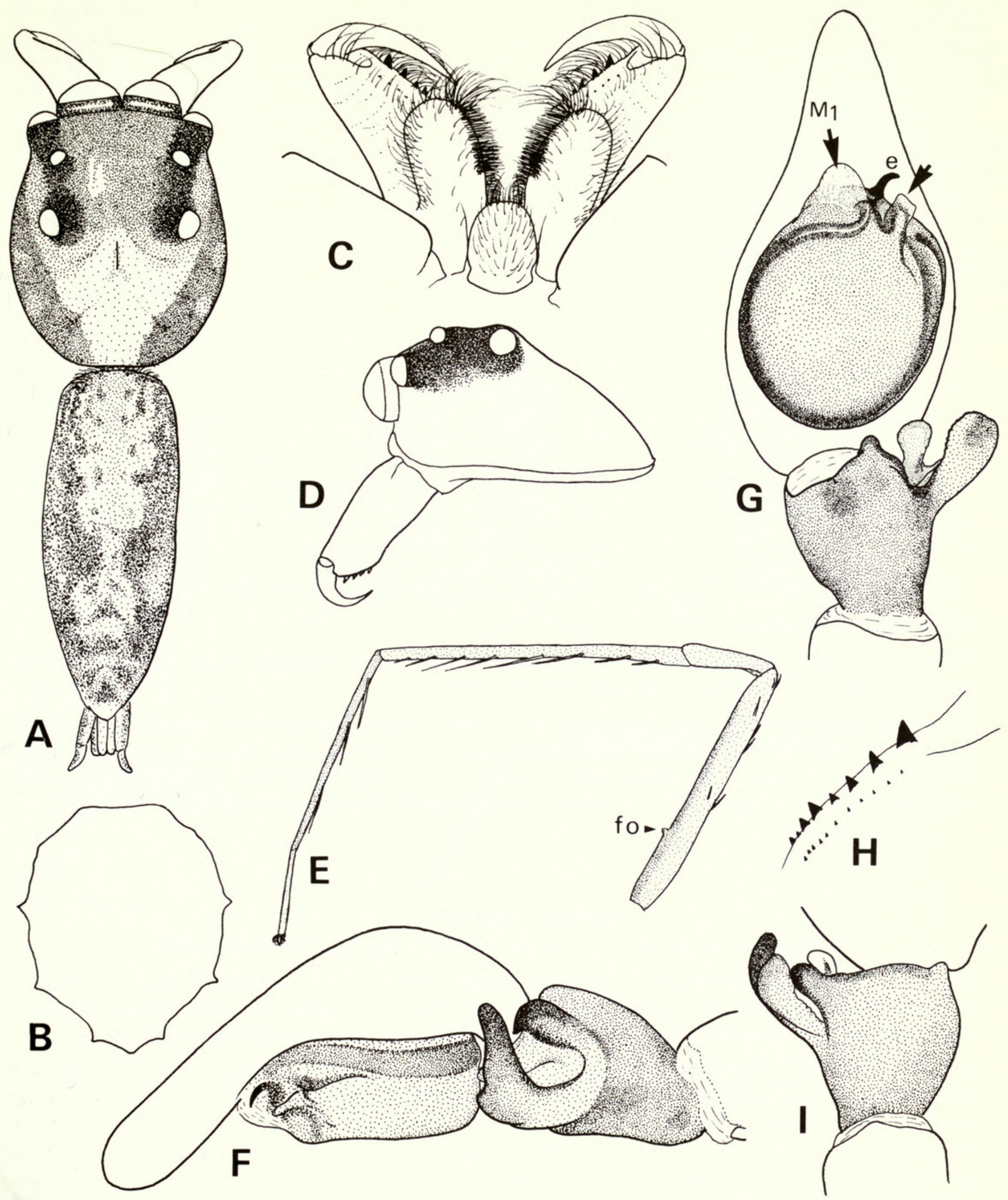

Fig. 4. Spartaeus thailandicus Wanless ô, A, dorsal view; B, sternum; C, chelicerae, maxillae and labium; D, carapace, lateral view; E, leg I; F, palp, retrolateral view; G, palp, ventral view; H, cheliceral teeth; I, palpal tibia, dorsal view. Abbreviations: e, embolus; fo, femoral organ; M1, fan-shaped element of distal haematodocha. 
rubbed; spinnerets long and robust. Legs: very long and slender, femoral organ pronounced; legs I yellow-brown except for blackish streaks on sides of femora, a blackish tinge towards apices of metatarsi and whitish yellow tarsi; other legs whitish yellow to yellow-brown with apices of metatarsi and tarsi tinged black; clothed in scattered simple and feathery hairs - mostly rubbed; tarsi I-II and apices of metatarsi I with proventral row of specialised prey-capture setae; metatarsi II-III with basal fringe of fine curved filamentous setae. Spines strong and numerous; spination of leg I: metatarsus v 2-4-0, tibia v 4-6-7, femur p 1-1-1, d 0-2-2, r 0-1-1. Palp (Fig. 4F, G, I): element M1 of the distal haematodocha (see Wanless, 1984a) fan-shaped (Fig. 4G); element M2 is obscure and appears to have fused with the base of the embolus.

Dimensions $(\mathrm{mm})$ : total length $8 \cdot 5$; carapace length $3 \cdot 84$, breadth $3 \cdot 14$, height $2 \cdot 75$; abdomen length $4 \cdot 6$; eyes, anterior row $2 \cdot 7$, middle row $2 \cdot 04$, posterior row $2 \cdot 32$; quadrangle length 1.9 ( $49 \%$ of carapace length).

\begin{tabular}{lccccc} 
Leg & 1 & 2 & 3 & 4 & Palp \\
Femur & 6.40 & 3.84 & 3.56 & 4.56 & 1.60 \\
Patella & 2.60 & 1.72 & 1.44 & 1.60 & 0.88 \\
Tibia & 7.04 & 3.32 & $3 \cdot 16$ & 4.28 & 0.56 \\
Metatarsus & 5.36 & $3 \cdot 16$ & 3.64 & 5.28 & - \\
Tarsus & 1.96 & $1 \cdot 14$ & $1 \cdot 16$ & 1.36 & 1.68 \\
\hline Total & 23.36 & $13 \cdot 18$ & 12.96 & 17.08 & 4.72
\end{tabular}

Ratios: AM : AL : PM : PL :: $22: 13: 8 \cdot 5: 12 ;$ AL-PM-PL : 12-14; AM : CL :: $22: 5$.

Distribution. Thailand.

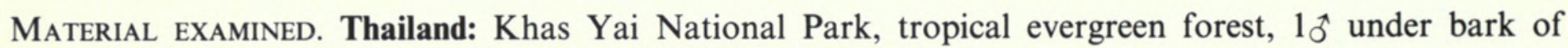
decomposing log, 17.iii.1984, P. D. Hillyard, BMNH. 1985.8.16.1.

NATURAL HISTORY. The male described above was found together with several harvestmen (Opiliones) under the bark of a fallen decomposing log. There was no evidence of a web, but it was noticeable that the legs of this species were comparatively much longer than those of $S$. wildtrackii, a character that may enable future collectors to distinguish the species in the field.

\section{Spartaeus wildtrackii sp. $\mathrm{n}$.}

(Figs 1; 2; 5A-E; 6A-D; 14A-C; 15A\&C; 16A-D; 17A-G; 18A-D)

DiAGNOSIS. S. wildtrackii seems to be most closely related to $S$. thailandica, but may be distinguished by the absence of a tegular apophysis and the form of the retrolateral tibial apophysis in males (Fig. 6A, B, D), and the presence of a postepigynal furrow in females (Fig. 5D).

FEMAlE hOLOTYPE, in fair condition. Carapace (Fig. 5A, B): weakly iridescent under some angles of illumination; orange-brown lightly tinged and mottled black with a broad yellow-brown tapering band on thoracic part and vague patches on sides; irregularly clothed in whitish hairs (mostly rubbed). Eyes: laterals with black surrounds; fringed by whitish and pale yellow hairs. Clypeus: sparsely clothed in black hairs. Chelicerae: robust, moderately long and more or less parallel; brownish orange lightly tinged black; thinly clothed in black hairs with dense promarginal scopula; promargin with six teeth, retromargin with nine or 12 denticles. Maxillae and labium: pale orangebrown lightly tinged with some grey. Sternum: pale yellow with darker margins. Coxae: pale yellow except first pair with blackish promarginal sides. Abdomen: pale yellow with blackish markings and scattered clumps of whitish guanin; ventrally a broad black band from epigyne to spinnerets; spinnerets long and robust. Legs: long and slender; legs I pale yellow to light orange-brown with vague sooty markings and a proventral black stripe on femora that appears iridescent green under 

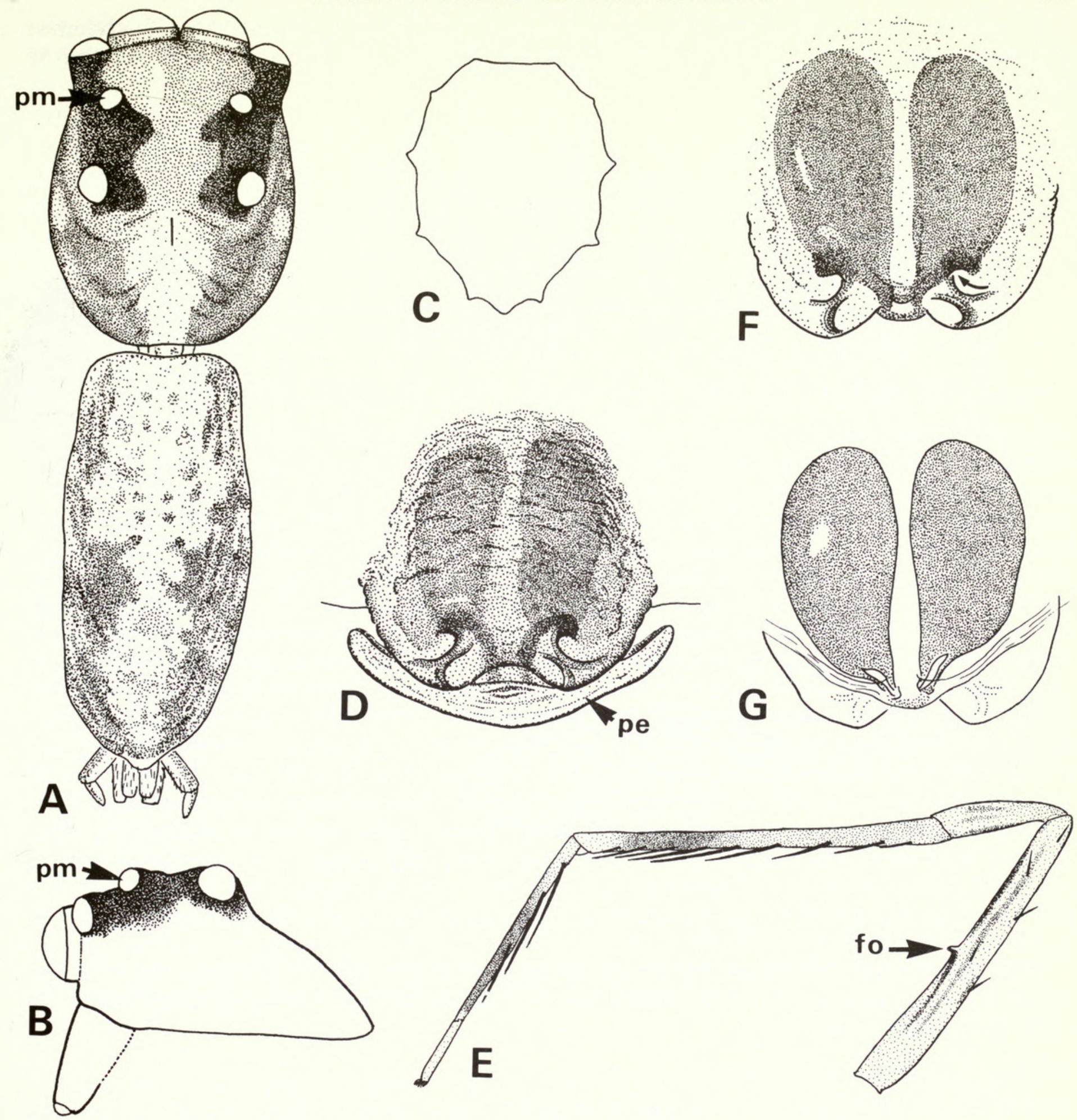

Fig. 5. Spartaeus wildtrackii sp. n., holotype శో: A, dorsal view; B, carapace, lateral view; D, epigyne. Paratype ô: C, sternum; E, leg, I. Paratype o: F, vulva, ventral view; G, vulva, dorsal view. Abbreviations: pe, postepigynal furrow; pm, posterior median eye; fo, femoral organ.

some angles of illumination; other legs similar except femoral stripe lacking; also, dorsal spines arise from black spots; sparsely clothed in simple and feathery hairs, (Fig. 16D), mostly rubbed, with proventral row of specialized prey-capture setae on tarsi I-II (Fig. 17B, G) and apices of metatarsi I; proximal half of metatarsi II-III with scanty ventral fringe of fine curved filamentous setae (Fig. 17A, C-F). Spines strong and numerous; spination of leg I: metatarsus v 3-2-0, p 0-1-0, tibia v 5-8-7, femur d $0-2-1$. Palp: with terminal claw; pale yellow with greyish patch on tarsus; clothed in pale yellow and light greyish hairs. 
Dimensions $(\mathrm{mm})$ : total length $6 \cdot 4$; carapace length $2 \cdot 72$, breadth $2 \cdot 28$, height $1 \cdot 52$; abdomen length 3.68 ; eyes, anterior row $2 \cdot 08$, middle row $1 \cdot 48$, posterior row $1 \cdot 75$; quadrangle length $1 \cdot 58$ ( $58 \%$ of carapace length).

\begin{tabular}{lccccc} 
Leg & 1 & 2 & 3 & 4 & Palp \\
Femur & 3.24 & $2 \cdot 56$ & $2 \cdot 56$ & $3 \cdot 16$ & 1.06 \\
Patella & 1.50 & $1 \cdot 16$ & 1.00 & 1.06 & 0.60 \\
Tibia & 3.16 & $2 \cdot 20$ & $2 \cdot 20$ & 3.04 & 0.64 \\
Metatarsus & 1.92 & 1.74 & 2.36 & 3.20 & - \\
Tarsus & 0.84 & 0.78 & 0.92 & 1.08 & 1.16 \\
\hline Total & 10.66 & 8.44 & 9.04 & 11.54 & 3.46
\end{tabular}

Ratios: AM : AL : PM : PL :: 16.5 : $11: 7: 11 ; \mathrm{AL}-\mathrm{PM}-\mathrm{PL}:: 10-10 ; \mathrm{AM}: \mathrm{CL}:: 16 \cdot 5: 3 \cdot 5$.

MALE PARATYPE, in good condition. Carapace: dark brown with dull orange-brown eye region and yellow-brown markings on thoracic part; clothed in fine recumbent light greyish and pale amber hairs. Eyes: laterals with black surrounds; fringed by pale yellow, whitish and amber hairs; also, a dense matt of short hairs behind anterior medians. Clypeus: tinged black, sparsely clothed in black hairs. Chelicerae: long, robust and slightly diverging; dark brown heavily tinged black; shiny; thinly clothed in black hairs with dense promarginal scopula; fang robust and curved with basal protuberance; promargin with eight teeth, retromargin with 12 (Fig. 6C). Maxillae and labium: orange-brown to yellow-brown tinged grey. Sternum (Fig. 5C): pale greenish yellow with darker margins; thinly clothed in greyish simple and feathery hairs. Coxae: pale greenish yellow with black promarginal stripe. Abdomen: yellow-brown suffused and mottled black; clothed in light and dark amber hairs with two spots comprised of whitish guanin; venter yellow-brown with grey-black band clothed in black feathery hairs from epigastric furrow to spinnerets; spinnerets long and robust. Legs: long and slender; femoral organ well developed (Fig. 5E; 14A-C); legs I pale greenish yellow to light orange brown with sooty markings and blackish longitudinal stripes on femora that shine iridescent green under some angles of illumination; thinly clothed in simple and black feathery hairs with some whitish ones on tarsi; specialized prey capture and filamentous hairs as in female. Spination of leg I: metatarsus v 3-1-1, p 0-0-1, r 1-0-0; tibia v 5-7-6; femur d 0-2-1, p 0-1-1. Palp (Fig. 6A, B, D): yellow-brown to light orange-brown with black iridescent stripe on underside of femora.

Dimensions $(\mathrm{mm})$ : total length 6.96; carapace length 3.36 , breadth $2 \cdot 68$, height 1.92 ; abdomen length 3.8 ; eyes, anterior row 2.32 , middle row 1.62 , posterior row 1.96; quadrangle length 1.8 ( $54 \%$ of carapace length).

\begin{tabular}{lccccc} 
Leg & 1 & 2 & 3 & 4 & Palp \\
Femur & 5.40 & 3.44 & 3.36 & 4.28 & 2.20 \\
Patella & 2.20 & 1.48 & 1.28 & 1.36 & 1.38 \\
Tibia & 5.68 & 3.16 & 3.08 & 4.20 & 1.08 \\
Metatarsus & 3.48 & 2.56 & 3.24 & 4.58 & $\underline{1.88}$ \\
Tarsus & 1.22 & 0.92 & 1.04 & 1.20 & 1.88 \\
\hline Total & 17.98 & 11.56 & 12.00 & 15.62 & 6.54
\end{tabular}

Ratios: AM : AL: : PM : PL :: $19: 11: 8: 11 ;$ AL—PM-PL :: $10: 13 ;$ AM : CL :: $19: 5$.

VARIATION. Male total length varies from 6.24 to $7.44 \mathrm{~mm}$, carapace length $2.72-3.36 \mathrm{~mm}$ (five specimens); female total length $6.0-6.96 \mathrm{~mm}$, carapace length $2.56-3.36 \mathrm{~mm}$ ( 10 specimens).

In two females the arthrodial membrane between the chelicerae and the clypeus is evident as a narrow white band, whereas it is broad and conspicuous in other specimens. However, to judge from the set of the chelicerae it is apparent that the phenomenon is the result of postmorten changes. 



Fig. 6. Spartaeus wildtrackii sp. n., paratype $\hat{\sigma}$, A, palp, ventral view; B, palpal tibia, dorsal view; C, cheliceral teeth; D, palp, retrolateral view; E, chelicerae, maxillae and labium. Abbreviations: rta, retrolateral tibial apophysis, tf, tegular furrow; va, ventral apophysis.

NATURAL HISTORY. S. wildtrackii has so far only been found in lowland rainforest on the trunks of large trees covered in lichen or moss, against which the spiders are well camouflaged. A number of specimens were seen both at night and during the day resting on bark beneath large silken webs $c a$. $5-6 \mathrm{~cm}$ constructed of glossy translucent silk that was often torn (Fig. 1,2). Their prey is unknown except for that of one specimen which was seen feeding on newly emerged moths, that were resting and evidently drying their wings. The spiders were not seen to jump, but it was noted that they were fast runners (P. D. Hillyard, pers. comm.).

Distribution. West Malaysia.

Material eXAmined. West Malaysia, P. D. Hillyard: Pahang State, Taman Negara, nr. Kuala Tahan, lowland primary rain forest: on tree trunks under sheet webs, 9.iii.1984, holotype + , BMNH. 1985.8.16.2,

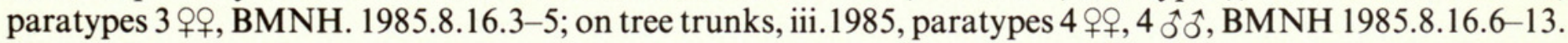
Negeri Sembilan State, Pasoh Forest Reserve, on tree trunks in lowland primary rain forest, iii.1985,

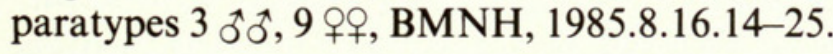

ETYMOLOGY. This species is named for the BBC television programme 'Wildtrack' which has done much to encourage children to care for the environment and take an interest in natural history. 
REMARKS. 1. Postepigynal furrows (Fig. 5D) are an unusual feature of salticid epigynes and to date have only been found in one other spartaeine i.e. Gelotia bimaculata Thorell. Their function is uncertain, but they may form part of the supporting mechanism that holds the male palp in position during copulation.

2. Loerbroks (1984) has recently drawn attention to conspicuous similarities in palpal structure between Misumena vatia (Clerck), a crab spider (Family Thomisidae) and Phaeacius Koch, a genus of flattened salticid that has also been classified in the Spartaeinae. Futhermore, he has shown that in $M$. vatia, and probably all other thomisids, the ventral apophysis locks into the regular ridge as the palpal elements expand and rotate during copulation. The ventral apophysis (Figs 6A; 13F) and tegular furrow (Fig. 6A) (= tegular ridge of Loerbroks) characteristic of all spartaeines are evidently homologous with those of thomisids and probably function in a similar manner. In $M$. vatia the inner surface of the ventral apophysis is covered in papillae (see Loerbroks 1984, Fig. 6) that evidently reduce friction between the apophysis and the rotating tegulum. Similar papillae might therefore be expected on the ventral apophysis of $S$. wildtrackii, but are absent (Fig. 18A). However, spicule-like papillae do occur on the inner surface of the retrolateral tibial apophysis (Fig. 18B-D) and presumbly they too could reduce surface friction, although on the otherhand they may serve to prevent the apophysis from sliding out of position during copulaton.

Although genital structures are not generally used in assessing relationships at the familial level, they are considered here because ventral apophyses and tegular furrows are not known to occur in other spider families. They may have arisen independently, but as Loerbroks (1984) has already stated they may provide evidence of a phylogenetic link between salticids and thomisids. Additional evidence is provided by Homann (1971) who has shown that the anterior median eyes (principal eyes) of most spiders are small and have few visual cells, whereas those of salticids and thomisids are unique in possessing many visual cells which provide for 'sharp vision'. These optical similarities may be convergent as Homann regards thomisid eyes as being structurally closer to those of wolf spiders (Family Lycosidae). Future studies will have to take account of the genitalial similarities noted by Loerbroks since these can be interpreted as supportive of a sister group relationship between salticids and thomisids.

\section{Genus MINTONIA Wanless}

Mintonia Wanless, 1984a: 157. [definition, diagnosis and key to species].

This small oriental genus comprises nine species including two new taxa described below. The majority of species have been collected from Borneo, but the genus is also known from Java, Sumatra and Peninsular Malaya. Males are of particular interest because they possess femoral organs (Fig. 9D; 19A-C), a presumptive sex pheromone dispersal site, and retrolateral tibial apophyses, some of which bear openings (Fig. 9E arrowed; 20A, B). Unfortunately nothing is known of their natural history.

\section{Mintonia melinauensis Wanless}

(Fig. 7A-E)

Mintonia melinauensis Wanless, 1984a: 165, o $^{\uparrow}$ holotype, Sarawak (BMNH) [examined].

DIAGNOSIs. Males can be recognized by the heavy inward curving embolus and by the form of the retrolateral tibial apophysis (see Wanless, 1984a, Fig. 13); females by the structure of the epigyne (Fig. 7E) which is clearly different from that of other females of the genus.

Female, formerly undescribed, in fair condition. Carapace (Fig. 7A, D): weakly iridescent under some angles of illumination; orange-brown lightly mottled black with paler lateral markings and band from fovea to posterior margin; rubbed, but otherwise clothed in whitish pubescent hairs. Eyes: laterals with black surrounds; fringed by whitish hairs. Clypeus: lightly tinged with some black; sparsely clothed in fine whitish hairs with several long bristles. Chelicerae: orange-brown suffused with some black proximally; shiny, thinly clothed in long pale orange hairs with moderately dense promarginal scopulae; promargin with three teeth, retromargin with six (Fig. 7B). 



Fig. 7. Mintonia melinauensis Wanless, o : A, dorsal view; B, cheliceral teeth; C, sternum; D, carapace, lateral view; E, epigyne.

Maxillae: light orange-brown with whitish yellow inner distal margins. Labium: brownish orange tipped whitish yellow. Sternum (Fig. 7C): pale yellow with darker margins; thinly clothed in fine hairs. Coxae: pale greyish yellow. Abdomen: rubbed; whitish yellow with vague greyish markings; spinnerets whitish yellow with outer sides of anteriors tinged black. Legs: moderately long and robust; whitish yellow to orange brown; spines strong and numerous. Spination of leg I; metatarsus v $2-2-1, \mathrm{p} 1-0-1, \mathrm{~d} 0-0-2, \mathrm{r} 1-0-0$; tibia v $2-2-2$, p $1-0-1, \mathrm{r} 0-0-1$; patella $\mathrm{p} 0-1-0, \mathrm{r} 0-1-0$; femur d $0-2-3$. Palp: whitish yellow with sooty markings except for pale orange brown tarsi. Epigyne (Fig. 7E): clothed in fine pale yellowish hairs.

Dimensions $(\mathrm{mm})$ : total length $5 \cdot 2$; carapace length $2 \cdot 24$, breadth $1 \cdot 76$, height $1 \cdot 44$; abdomen length 3.04 ; eyes, anterior row 1.64 , middle row 1.48 , posterior row 1.64 ; quadrangle length 1.2 ( $53 \%$ of carapace length).

\begin{tabular}{lccccc} 
Leg & 1 & 2 & 3 & 4 & Palp \\
Femur & 1.48 & 1.46 & 1.48 & 1.80 & 0.80 \\
Patella & 0.86 & 0.81 & 0.71 & 0.76 & 0.48 \\
Tibia & 1.12 & 1.04 & 1.12 & 1.44 & 0.52 \\
Metatarsus & 0.96 & 0.94 & 1.16 & 1.60 & - \\
Tarsus & 0.58 & 0.57 & 0.60 & 0.68 & 0.72 \\
\hline Total & 5.00 & 4.82 & 5.07 & 6.28 & 2.52
\end{tabular}

Ratios: AM : AL : PM : PL:: $13: 8: 5: 8 ; \mathrm{AL}-\mathrm{PM}-\mathrm{PL}:: 7 \cdot 5-8 \cdot 5 ; \mathrm{AM}: \mathrm{CL}:: 13: 2 \cdot 5$. 

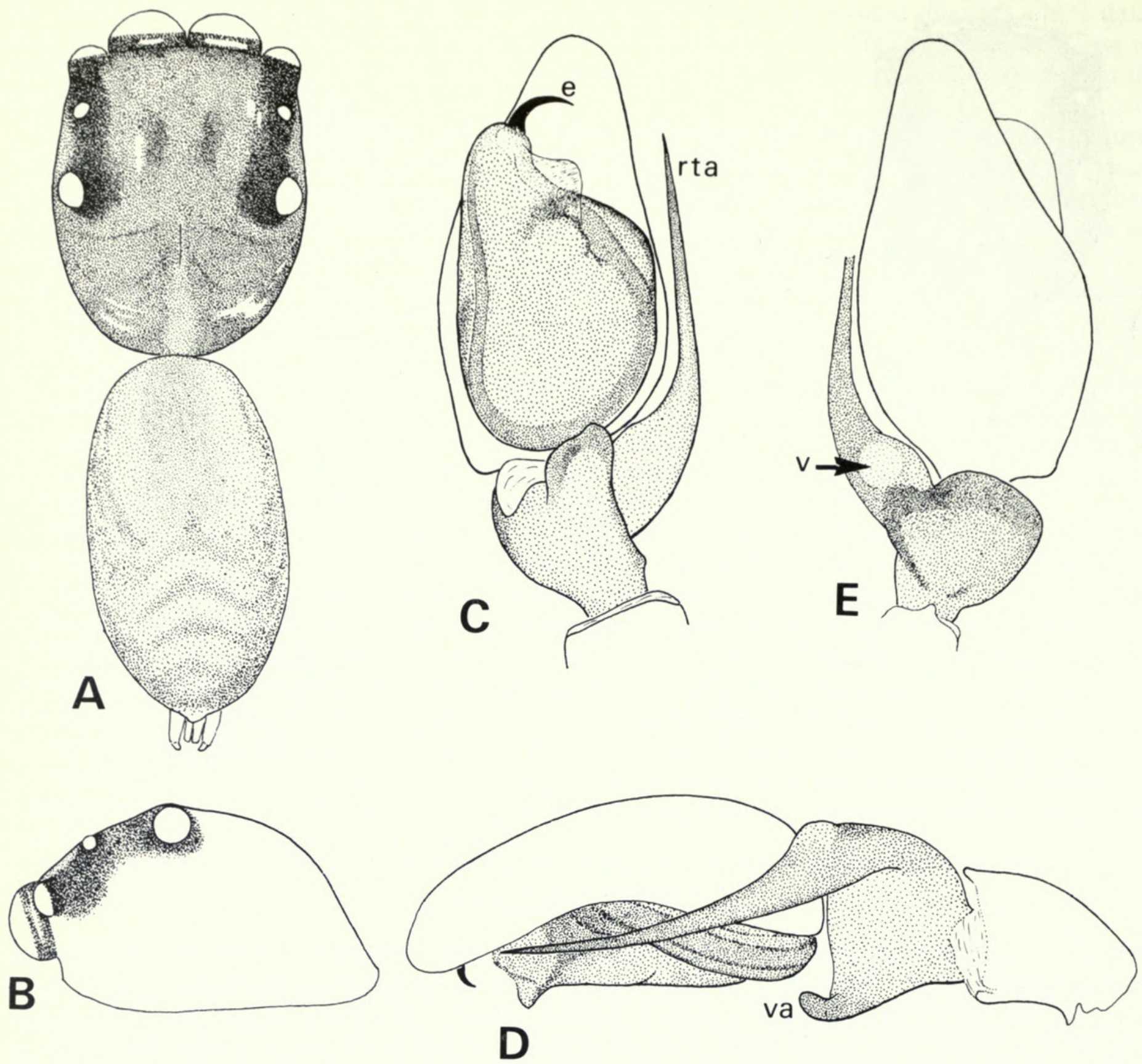

Fig. 8. Mintonia caliginosa sp. n., holotype $\widehat{\jmath}$ : A, dorsal view; B, carapace, lateral view; C, palp, ventral view; D, palp, retrolateral view; E, palp, dorsal view. Abbreviations: e, embolus; rta, retrolateral tibial apophysis; v, vacuole; va, ventral apophysis.

Material eXAmined. Type data given in synonymy. Sarawak: Gunung Mulu National Park, Environs of camp 3, moss forest, 19, from moss covered tree trunk, 27.5.78, F. R. Wanless, Royal Geographic Society/ Sarawak Government Expedition. (BMNH).

\section{Mintonia caliginosa sp. n.}

(Fig. 8A-E; 19A-C)

Diagnosis. A distinctive species easily recognized by the long retrolateral tibial apophysis (Fig. 8D).

Female. Unknown.

Male holotyPe, rubbed otherwise in fair condition. Carapace (Fig. 8A, B): orange-brown lightly tinged and mottled black; shiny and weakly iridescent under some angles of illumination. Eyes: laterals with black surrounds; fringed by whitish and pale amber hairs, mostly rubbed. Clypeus edged black below anterior median eyes; rubbed - a few whitish hairs remaining. Chelicerae: light brown with black markings, shiny, thinly clothed in scattered fine hairs; promargin with three 
teeth, retromargin with four or five. Maxillae: light yellowish brown. Labium: blackish edged pale yellow-brown. Sternum: yellow-brown, shiny, thinly clothed in fine greyish hairs. Abdomen: yellow-brown lightly tinged and mottled black with a poorly defined orange-brown scutum and chevrons dorsally, and three rather vague longitudinal bands ventrally; spinnerets yellow-brown lightly tinged black. Legs: moderately long and slender; femoral organ (Fig. 19A-C) a low tubercle; yellow-brown tinged with some black except metatarsi and tarsi which are darkerorange-brown tinged black, also on underside of femora I-II a transverse blackish patch; spines strong and numerous. Spination of leg I: metatarsus v $2-0-0, \mathrm{p} 1-1-1, \mathrm{~d} 0-1-2, \mathrm{r} 1-1-1$; tibia v $2-2-2$, p 1-1-0, d 1-1-0, r 1-1-0; patella p 0-1-0, r 0-1-0; femur d 0-2-4. Palp (Fig. 8C-E): the retrolateral tibial apophysis is broken at point arrowed in Fig. 8E; however, note that in Fig. 8Ci.e. the same palp but drawn from a different angle, the appearance of the retrolateral tibial apophysis has been reconstructed from the apophysis of the other palp.

Dimensions $(\mathrm{mm})$ : total length $3 \cdot 8$; carapace length $1 \cdot 76$, breadth $1 \cdot 36$, height $1 \cdot 1$; abdomen length 1.92 ; eyes, anterior row 1.27 , middle row 1.2 , posterior row 1.35 ; quadrangle length 0.94 (53\% of carapace length).

\begin{tabular}{lccccc} 
Leg & 1 & 2 & 3 & 4 & Palp \\
Femur & 1.16 & $1 \cdot 12$ & $1 \cdot 19$ & 1.46 & 0.60 \\
Patella & 0.60 & 0.60 & 0.52 & 0.56 & 0.32 \\
Tibia & 0.84 & 0.80 & 0.88 & $1 \cdot 16$ & 0.24 \\
Metatarsus & 0.80 & 0.78 & 0.88 & 1.28 & - \\
Tarsus & 0.52 & 0.48 & 0.56 & 0.60 & 0.72 \\
\hline Total & 3.90 & 3.78 & 4.03 & 5.06 & 1.88
\end{tabular}

Ratios: AM : AL : PM : PL :: 9.5 : 5·5 : 3·5 : 5.5; AL—PM—PL :: 6-7; AM : CL :: 9.5 : 3·3.

Distribution. Borneo, Sabah.

Material eXamined. Borneo: Sabah, Tuaran Division, Mt. Kinabalu National Park, Power StationLayang Layang, cloud forest, holotype ơ, 2000-2800 m, 7.ii.1976 P. T. Lehtinen, (TU, Turku).

REMARK. The presence of a vacuole in the base of the retrolateral tibial apophysis suggests that there is probably a distal opening. There is insufficient material for this to be confirmed by SEM.

ETYMoLOGy. The specific name is from the Latin meaning misty, cloudy places.

\section{Mintonia silvicola $\mathrm{sp} . \mathrm{n}$.}

(Fig. 9A-G)

Diagnosis. M. silvicola seems to be most closely related to $M$. tauricornis Wanless, but may be readily distinguished by the syringe-shaped retrolateral tibial apophysis (Fig. 9E).

Female. Unknown.

MALE HOLOTYPE, rubbed, also right leg I missing, otherwise in fair condition. Carapace (Fig. 9A, B): weakly iridescent under some angles of illumination; orange-brown with faint blackish mottling on sides. Eyes: laterals with black surrounds; anteriors fringed by whitish hairs. Clypeus: orange-brown with blackish margin below anterior median eyes and vague yellow-brown markings clothed in whitish hairs below anterior laterals. Chelicerae: yellow-brown, shiny, clothed in white hairs proximally and scattered brown hairs distally with dense promarginal scopulae; promargin with three teeth, retromargin with eight (Fig. 9G). Maxillae: yellow-brown with inner distal margins paler. Labium: yellow-brown faintly tinged grey. Sternum: pale yellow with vague darker margins; thinly clothed in fine pale yellow hairs. Coxae: pale yellow. Abdomen: pale yellow 

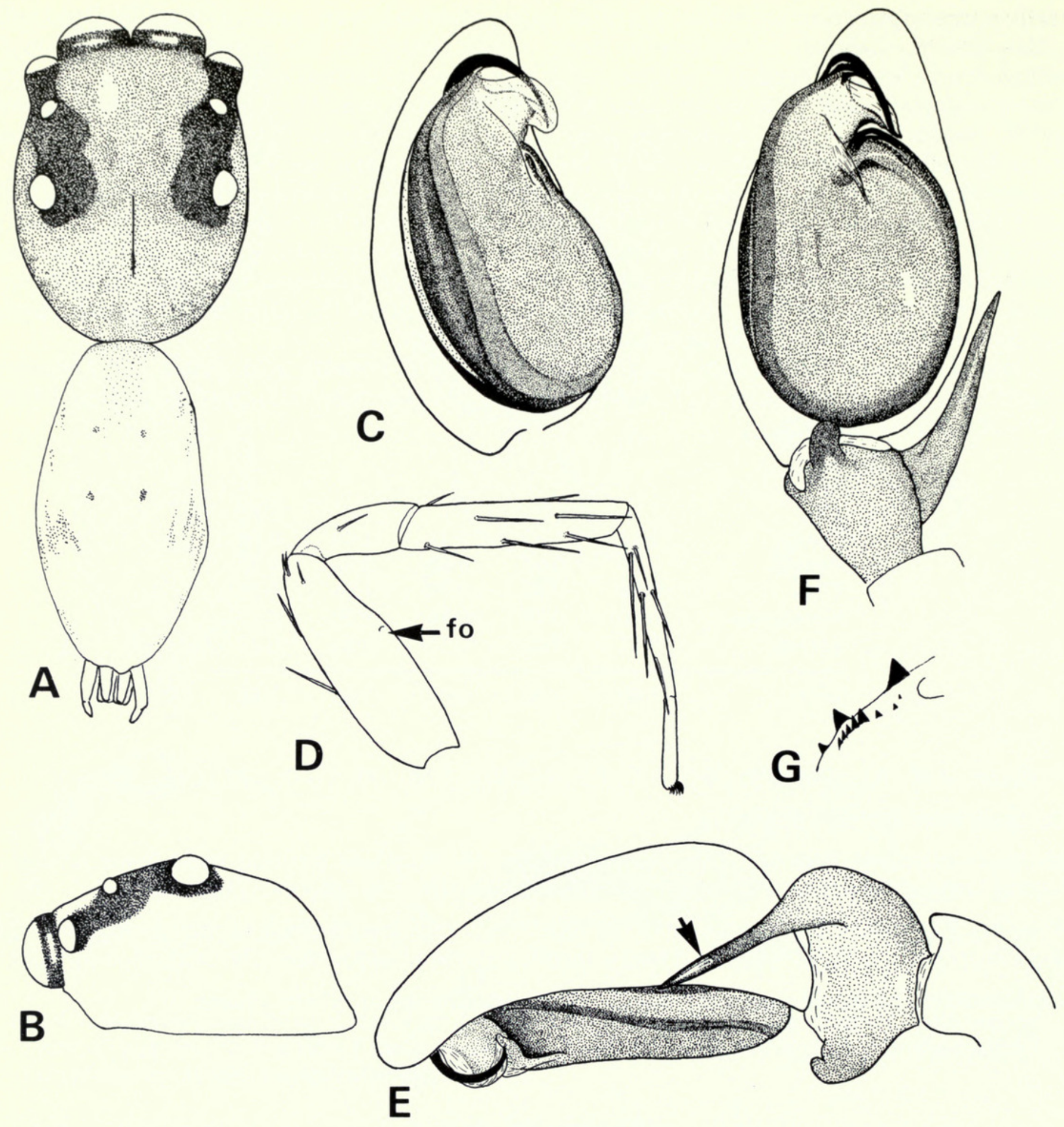

Fig. 9. Mintonia silvicola sp. n., holotype $\widehat{\delta}: \mathrm{A}$, dorsal view; B, carapace, lateral view; C, palp, ventrolateral view; D, leg I; E, palp, retrolateral view; F, palp, ventral view; G, cheliceral teeth. Abbreviation: fo, femoral organ.

with vague sooty markings and two pairs of sigilla; rubbed; spinnerets moderately long, yellowbrown. Legs: moderately long and slender; specialized prey capture and metatarsal setae lacking; femoral organ appearing as a low dark amber mound; legs I pale yellow to yellow-brown with underside of femora tinged black; other legs pale yellow grading to yellow-brown distally with ventral longitudinal grey stripe on tibiae II-III; spines numerous and moderately strong. Spination of leg I: metatarsus v 2-0-0, r $1-1-1, \mathrm{~d}$ 0-2-2, p 1-1-1; tibia v 2-2-2, p 1-1-0, d 1-1-0, r 1-1-0; patella p 0-1-0, r 0-1-0; femur d 0-2-4. Palp (Fig. 9C, E, F): element M2 lies above the embolus and the tegular ledge is poorly developed; the opening of the retrolateral tibial apophysis (arrow, Fig. 9E) is distinct. 
Dimensions $(\mathrm{mm})$ : total length $5 \cdot 1$; carapace length $2 \cdot 24$, breadth $1 \cdot 88$, height $1 \cdot 44$; abdomen length 2.6 ; eyes, anterior row 1.71 , middle row 1.48 , posterior row 1.64 ; quadrangle length 1.32 ( $58 \%$ of carapace length).

\begin{tabular}{lccccc} 
Leg & 1 & 2 & 3 & 4 & Palp \\
Femur & 1.72 & 1.72 & 1.72 & 2.04 & 0.84 \\
Patella & 0.88 & 0.84 & 0.76 & 0.80 & 0.40 \\
Tibia & 1.36 & 1.28 & 1.34 & 1.64 & 0.34 \\
Metatarsus & 1.28 & 1.26 & 1.44 & 1.80 & - \\
Tarsus & 0.64 & 0.64 & 0.72 & 0.76 & 1.12 \\
\hline Total & 5.88 & 5.74 & 5.98 & 7.04 & 2.70
\end{tabular}

Ratios: AM : AL : PM : PL :: $14: 8: 5 \cdot 4: 8 ;$ AL—PM-PL :: 8-9·5; AM : CL :: $14: 3$.

Distribution. West Malaysia.

Material eXAmined. West Malaysia: Pahang State, Taman Negara, holotype ${ }^{\wedge}$, from buttress of large tree, lowland rain forest nr. Kuala Tahan, 3-10.iii.1984. P. D. Hillyard, BMNH. 1985.8.21.1.

ETYMOLOGY. The specific name is from the Latin meaning inhabiting woods.

\section{Genus TARAXELLA Wanless}

Taraxella Wanless, 1984a: 155. [definition and diagnosis].

This genus was originally erected on the basis of a single male of Taraxella solitaria Wanless, from Sarawak. Subsequent collections have produced four new species, described below, that necessitate modifications to the original generic definition.

Definition. Spiders small to medium in size, i.e. between 2.0 and $8.0 \mathrm{~mm}$ in length; males sometimes with conspicuous encircling band on the carapace; sexual dimorphism sometimes evident in colour patterns.

Carapace. high, longer than broad, widest at about level of coxae II-III; fovea long and sulciform, apex at level of centre of posterior lateral eyes. Eyes: anterior medians more or less level or weakly procurved in frontal view; posterior medians small to relatively large; posterior laterals with outer margins of lenses set inside or at level of, lateral margins of carapace when viewed from above; entire quadrangle length between $57-65 \%$ of carapace length. Clypeus: low to moderately high. Chelicerae: promargin with five or seven teeth, retromargin with seven or nine denticles. Legs: moderately long and slender; femoral organs lacking; specialized prey capture tarsal setae and filamentous metatarsal setae also lacking. Female palps: moderately long and slender with apical claw. Epigynes: interspecifically distinct, see descriptions; vulvae not examined, insufficient material. Male palps: complex and interspecifically distinct; retrolateral tibial apophyses complex, sometimes bifid with sharp slender prongs, or evidently reduced with associated stout setae; apophyses $\mathrm{X}$ and $\mathrm{Y}$ variable in development; embolus short slender and gently curved, and for the most part obscured, in ventral view, by tegular apophyses X and occasionally $\mathrm{Y}$; tegular furrow and ventral apophysis usually conspicuous; M1, see Wanless 1984a, a delicate fan-shaped lamella that protrudes beyond the distal edge of the tegulum. Expanded palps not examined.

DiaGNOSIs. Distinguished from other spartaeines by the conformation of the embolus of the male palp which is almost completely obscured, in ventral view, by tegular apophyses ' $\mathrm{X}$ ' and occasionally ' $Y$ '.

An identification key is not provided as the five known species are easily separated from one another by the structure of the palpal organs and epigynes.

INTERSPECIFIC RELATIONSHIPS. To judge from the structure of the tibia of the male palpal organs $T$. solitaria, $T$. petrensis $\mathrm{sp}$. $\mathrm{n}$., and $T$. hillyardi $\mathrm{sp} . \mathrm{n}$., form a closely related group since they all possess retrolateral tibial apophyses with a sharp dorsal prong. T. sumatrana sp. n., and T. reinholdae 



Fig. 10. Taraxella hillyardi sp. n., holotype $\widehat{乛}:$ A, dorsal view; B, carapace, lateral view; C, leg I; D, palpal tibia, dorsal view; E, palp, retrolateral view; F, palp, ventral view. Abbreviations: al, anterior lateral eye; am, anterior median eye; dh, distal haematodocha; e, embolus; pl, posterior lateral eye; pm, posterior median eye; tf, tegular furrow; va, ventral apophysis.

would also appear to form a natural group as they possess conspicuous fringes of unusually stout setae, and lack retrolateral tibial apophyses with sharp dorsal prongs.

\section{Taraxella hillyardi sp. $\mathrm{n}$.}

(Fig. 10A, F)

Diagnosis. $T$. hillyardi seems to be most closely related to $T$. petrensis and $T$. solitaria, but can be easily distinguished by the bifid retrolateral tibial apophysis (Fig. 10E).

FEMALE. Unknown.

MALE HOLOTYPE, in fair condition. Carapace (Fig. 10A, B): weakly iridescent under some angles of illumination; light orange-brown tinged black with a broad yellowish encircling band on sides and also a black marginal band extending posteriorly from level of coxae I; rubbed. Eyes: laterals with 
black surrounds; sparsely fringed in pale amber and whitish hairs. Clypeus: greyish with black markings below anterior median eyes and whitish yellow stripes below anterior laterals; sparsely fringed by whitish hairs. Chelicerae: yellow-brown with extensive patches on facies; shiny; thinly clothed in fine clear hairs and some blackish ones with dense promarginal scopulae; promargin with five teeth; retromargin with eight denticles. Maxillae and labium: pale yellow with vague sooty markings. Coxae: yellow-brown. Abdomen: dorsum and sides pale yellow-brown suffused and mottled black, venter pale yellow brown suffused black in region of tracheal spiracle; spinnerets moderately long; anteriors and posteriors suffused black, medians pale yellow. Legs Fig. 10C): moderately long and slender; generally yellow-brown tinged with some black, with incomplete annuli on femora and blackish tibiae particularly of legs I and IV; spines moderately strong and numerous. Spination of leg I: metatarsus v $2-0-0$, p. $1-1-1$, d $0-2-2$, r $1-1-1$; tibia v $2-2-2$, p $0-1-1$, d 1-1-0, r 1-1-0; patella p 0-1-1, r 0-1-0; femur d 0-2-3, p 0-0-1. Palp (Fig. 10D-F): yellowbrown to orange-brown mottled black with patches of white hairs on patella and apices of femur, otherwise clothed in black hairs and scattered white ones with greyish scopula on cymbium.

Dimensions $(\mathrm{mm})$ : total length 3.9 ; carapace length 1.76 , breadth 1.53 , height 1.2 ; abdomen length 1.84 ; eyes, anterior row 1.56 , middle row 1.24 , posterior row 1.52 ; quadrangle length 1.07 ( $60 \%$ of carapace length).

\begin{tabular}{lccccc} 
Leg & 1 & 2 & 3 & 4 & Palp \\
Femur & 1.36 & 1.28 & 1.28 & 1.64 & 0.68 \\
Patella & 0.76 & 0.63 & 0.56 & 0.64 & 0.33 \\
Tibia & 1.12 & 0.96 & 1.00 & 1.39 & 0.36 \\
Metatarsus & 1.02 & 0.96 & 1.12 & 1.60 & -1.72 \\
Tarsus & 0.53 & 0.52 & 0.56 & 0.66 & 0.72 \\
\hline Total & 4.79 & 4.35 & 4.52 & 5.93 & 2.09
\end{tabular}

Ratios: AM : AL : PM : PL :: $13: 7: 3: 7 ; \mathrm{AL}-\mathrm{PM}-\mathrm{PL}:: 7-8 ; \mathrm{AM}: \mathrm{CL}:: 13: 3$.

Distribution. West Malaysia.

MATERIAL EXAMINED. West Malaysia: Gunong Jerai, (Kedeh), ca. $700 \mathrm{~m}$, holotype ${ }^{\wedge}$, shrub layer, along forest edge during middle of dry season, 15.ii.1983, P. D. Hillyard (BMNH. 1985.9.5.2).

ETYMology. This species is named after my colleague Mr P. D. Hillyard, BMNH, who collected many of the new species described in this paper.

\section{Taraxella petrensis sp. $\mathrm{n}$.}

(Fig. 11A-J)

DiAgnosis. $T$. petrensis seems to be most closely related to $T$. solitarius and $T$. hillyardi sp. n., but may be easily separated by the broad flange of the retrolateral tibial apophysis (Fig. 11J) in males and the structure of the epigyne (Fig. 11D) in females.

MALE HOLOTYPE, rubbed otherwise in good condition. Carapace (Fig. 11A, F): shiny and weakly iridescent in eye region; dark orange-brown suffused black with broad encircling creamy white band. Eyes: laterals with black surrounds; anteriors sparsely fringed in greyish hairs. Clypeus: creamy white with black spots near lower rims of anterior median eyes. Chelicerae: shiny black except for orange-brown inner margins; sparsely clothed in greyish hairs with dense promarginal scopulae; promargin with five teeth, retromargin with nine denticles (Fig. 11C). Maxillae and labium: greyish yellow faintly tinged black. Sternum: pale yellow-brown with darker margins; thinly clothed in light brownish hairs. Coxae: yellow-brown tinged grey. Abdomen: yellow-brown with dorsum and sides mottled black, also a vague black patch in area of tracheal slit; rubbed; spinnerets moderately long, black except for light greyish medians. Legs: moderately long and slender; yellow-brown heavily suffused black, especially on femora, patellae and tibiae; shiny and 

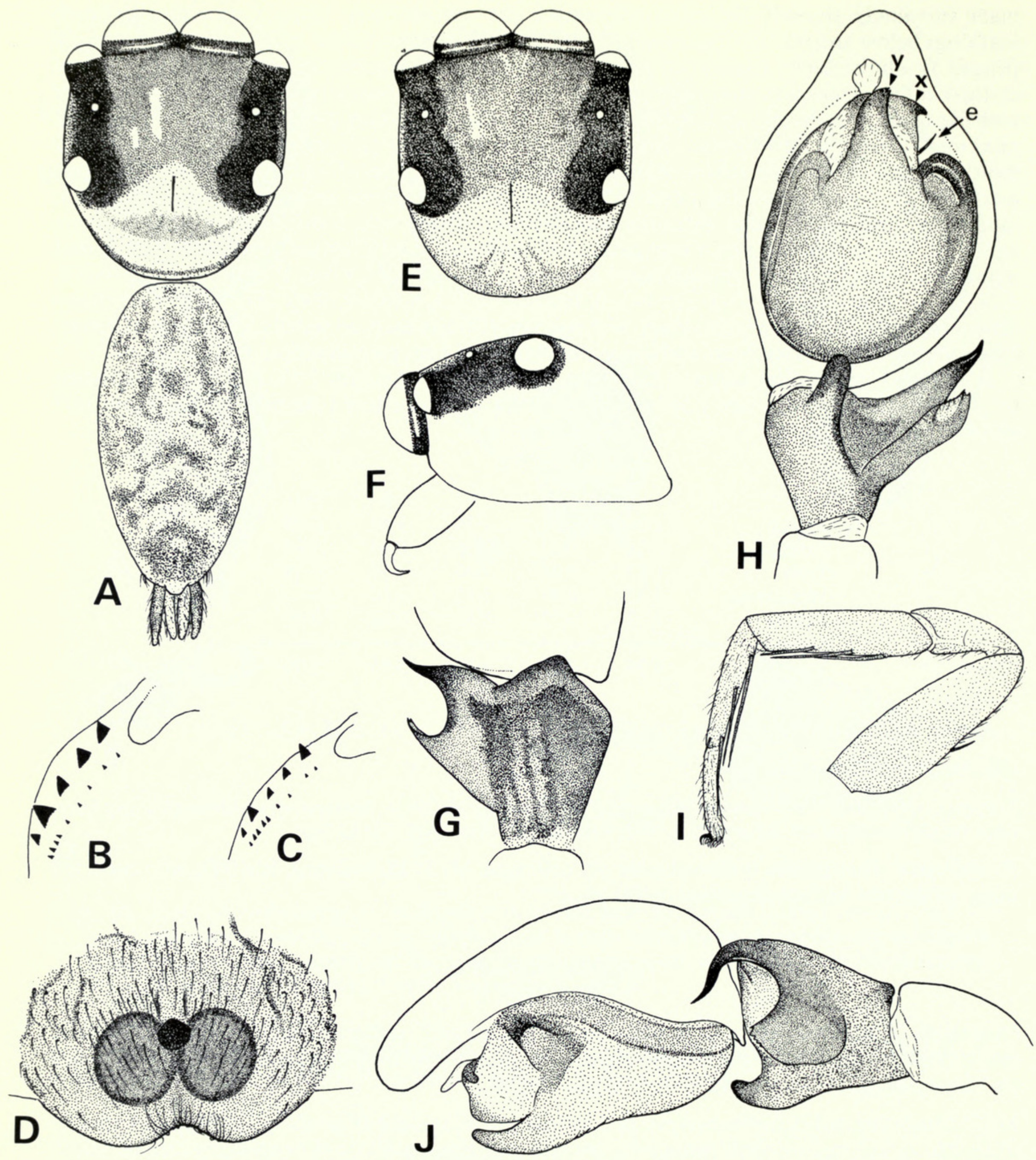

Fig. 11. Taraxella petrensis sp. $\mathrm{n}$. , holotype $\widehat{\delta}: \mathrm{A}$, dorsal view; $\mathrm{C}$, cheliceral teeth; $\mathrm{F}$, carapace, lateral view; G, palpal tibia, dorsal view; H, palp, ventral view; J, palp, retrolateral view. Paratype ठ $^{*}$ $\mathrm{B}$, cheliceral teeth; E, carapace, dorsal view; I, leg I. Abbreviation: e, embolus; ' $\mathrm{x}$ ' and ' $\mathrm{y}$ ' tegular apophyses.

iridescent under some angles or illumination; spines strong and numerous. Spination of leg I: metatarsus v $2-2-2$, p $1-0-0$, d $0-1-2$, r $1-0-0$; tibia v $1-3-2$, p $0-1-1, \mathrm{~d} 1-1-0, \mathrm{r} 0-0-1$; patella $\mathrm{p}$ $0-1-0$, r $0-1-0$; femur d 0-2-3. Palp (Fig. 11G, H, J): yellow to orange-brown suffused with some black especially on femur and cymbium; clothed in pale grey and black hairs. 
Dimensions $(\mathrm{mm})$ : total length $3 \cdot 72$; carapace length $1 \cdot 76$, breadth $1 \cdot 56$, height $1 \cdot 24$; abdomen length $2 \cdot 16$; eyes, anterior row 1.6 ; middle row 1.21 , posterior row 1.52 ; quadrangle length 1.08 ( $61 \%$ of carapace length).

\begin{tabular}{lccccc} 
Leg & 1 & 2 & 3 & 4 & Palp \\
Femur & 1.52 & 1.34 & 1.36 & 1.72 & 0.76 \\
Patella & 0.76 & 0.60 & 0.60 & 0.66 & 0.32 \\
Tibia & 1.24 & 1.00 & 1.04 & 1.42 & 0.36 \\
Metatarsus & 1.12 & 1.02 & 1.18 & 1.65 & - \\
Tarsus & 0.60 & 0.56 & 0.56 & 0.70 & 0.84 \\
\hline Total & 5.24 & 4.52 & 4.74 & 6.15 & 2.28
\end{tabular}

Ratios: AM : AL : PM : PL :: $13 \cdot 5: 7 \cdot 5: 2 \cdot 5: 7 \cdot 5 ; \mathrm{AL}-\mathrm{PM}-\mathrm{PL}:: 7 \cdot 5: 7 ; \mathrm{AM}: \mathrm{CL}:: 13 \cdot 5: 5$.

FEMALE PARATYPE, in fair condition. General habitus as in male except encircling cephalic band lacking. Carapace (Fig. 11E): light orange-brown lightly and finely reticulated black in eye region with blackish mottling on sides, also weakly iridescent under some angles of illumination; rubbed. Eyes: generally as in male, but sparsely fringed by pale amber hairs. Clypeus: light orange-brown faintly reticulated black; bald except for scattered fine marginal hairs and several long stiff hairs including usual triad in lower space between anterior median eyes. Chelicerae: yellow-brown lightly tinged with some black; shiny; sparsely clothed in brown hairs with dense promarginal scopulae; promargin with five teeth, retromargin with nine denticles (Fig. 11B). Maxillae and labium: yellow-brown. Sternum: pale yellow-brown with darker margins; sparsely clothed in fine hairs centrally and darker, longer ones towards margins. Abdomen: generally as in male except venter pale yellow-brown with scattered dark brown simple hairs and vague light greyish feathery hairs, otherwise rubbed; spinnerets similar to male, yellow-brown tinged black. Legs (Fig. 11I): moderately long and slender; light orange-brown faintly tinged with some black; sparsely clothed in brownish hairs; spines strong and numerous. Spination of leg I: metatarsus v $2-2-0, p 1-0-1, d$ $0-1-2$, r $0-0-1$; tibia v 2-3-1, p 0-1-1; patella p 0-1-0; femur d 0-2-2. Epigyne (Fig. 11D).

Dimensions $(\mathrm{mm})$ : total length 4.32 ; carapace length 1.96 , breadth $1 \cdot 72$, height 1.32 ; abdomen length $2 \cdot 28$; eyes, anterior row $1 \cdot 76$, middle row $1 \cdot 36$, posterior row $1 \cdot 72$; quadrangle length $1 \cdot 2$ (61\% of carapace length).

\begin{tabular}{lccccc} 
Leg & 1 & 2 & 3 & 4 & Palp \\
Femur & 1.58 & 1.44 & 1.44 & 1.76 & 0.76 \\
Patella & 0.84 & 0.74 & 0.64 & 0.70 & 0.43 \\
Tibia & 1.18 & 1.00 & 1.08 & 1.46 & 0.48 \\
Metatarsus & 1.04 & 1.00 & 1.20 & 1.68 & - \\
Tarsus & 0.60 & 0.56 & 0.63 & 0.64 & 0.67 \\
\hline Total & 5.24 & 4.74 & 4.99 & 6.24 & 2.34
\end{tabular}

Ratios: AM : AL : PM : PL :: 15: $8: 2: 8 ;$ AL—PM-PL :: 8-9; AM : CL :: $15: 2$.

Distribution. West Sumatra.

MATERIAL EXAMINED. West Sumatra: Harau Nature Reserve, near Payakumbu, holotype ô, on rock walls on edge of forest, ca. $600 \mathrm{~m}$, ii.1985, P. D. Hillyard, (BMNH. 1985.9.5.1); Taram, near Payakumbu, in secondary forest litter, paratype + , ii.1985, P. D. Hillyard, (BMNH. 1985.9.5.2).

ETYMoLOGY. The specific name is from the Latin meaning rocky places.

\section{Taraxella sumatrana sp. $\mathrm{n}$.}

(Fig. 12A-J)

DiAGNOSIs. Easily separated from other species of Taraxella by the dorsal fringe of stout setae on the palpal tibia (Fig. 12G, J) in males and by the structure of the epigyne in females (Fig. 12D). 

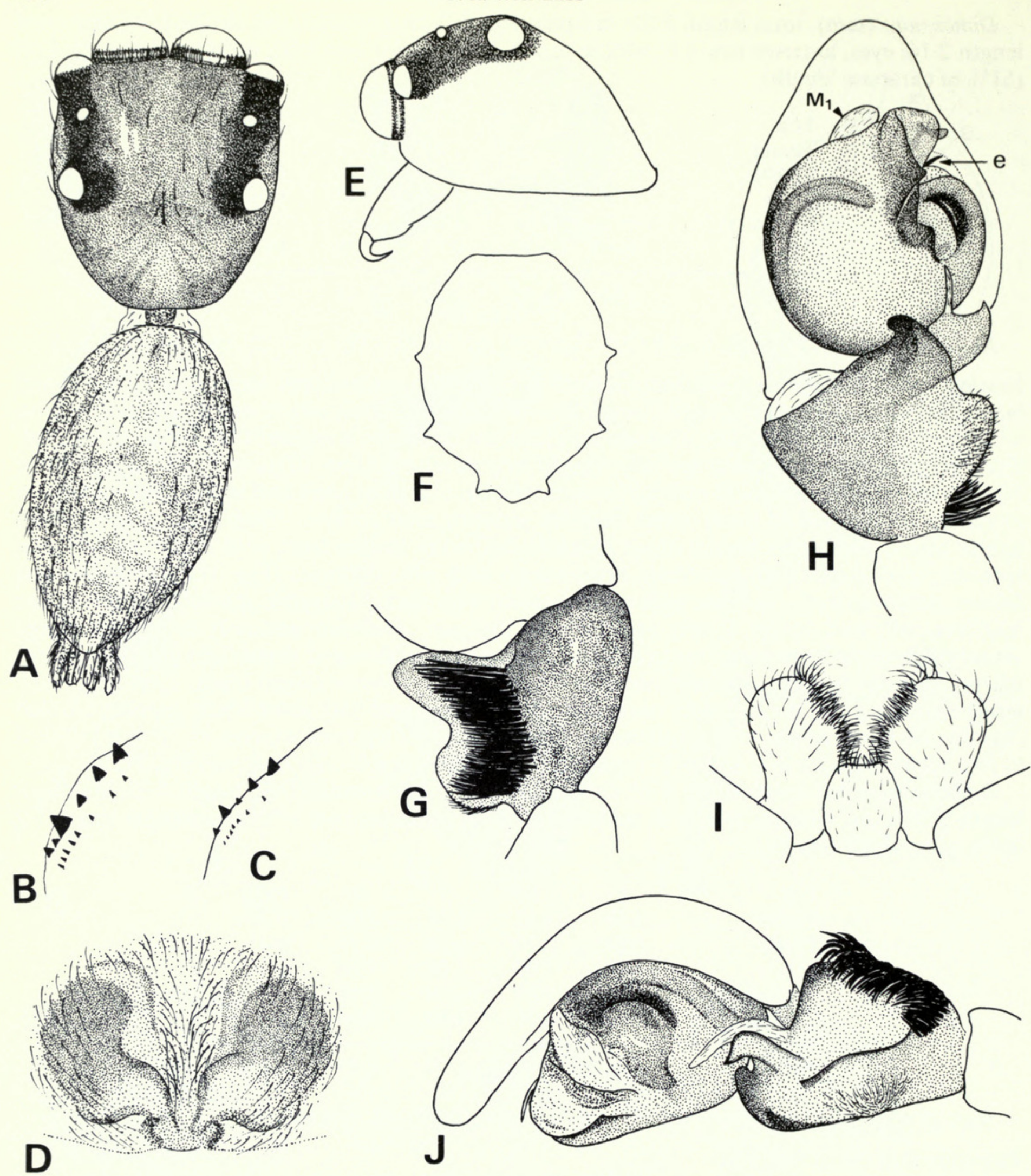

Fig. 12 Taraxella sumatrana sp. n., holotype + : A, dorsal view. B, cheliceral teeth; D, epigyne; F, sternum; I, maxillae and labium. Paratype $\widehat{\delta}$ : C, cheliceral teeth; E, carapace, lateral view; G, palpal tibia, dorsal view; $\mathrm{H}$, palp, ventral view; J, palp, retrolateral view. Abbreviations: e, embolus; M1, fan-shaped element of distal haematodocha.

Female holotype, in fair condition. Carapace (Fig. 12A): yellow-brown faintly tinged and mottled black with a metallic sheen under some angles of illumination; rubbed except for some scattered brown hairs. Eyes: laterals with black surrounds; fringed by light brownish hairs and some whitish ones below anterior median eyes. Clypeus yellow-brown tinged black with a few black bristles. Chelicerae: pale yellow-brown, shiny, sparsely clothed in brown-black hairs and some bristles with dense promarginal scopulae; promargin with six teeth, retromargin with eight 
denticles (Fig. 12B). Maxillae and labium: pale yellow-brown. Sternum (Fig. 12F): pale yellowbrown with darker margins; thinly clothed in stiff brown hairs. Coxae: pale yellow-brown. Abdomen: pale yellow-brown tinged and mottled black with vague chevrons dorsally; venter pale greyish yellow; mostly rubbed otherwise sparsely clothed in patches of recumbent dull amber lanceolate hairs, thinly interspersed with erect black hairs; spinnerets moderately long, pale yellow brown except anteriors tinged with some black. Legs: moderately long and slender; generally pale yellow-brown faintly tinged with some black; thinly clothed in pale greyish and black hairs; spines moderately strong and numerous. Spination of leg I: metatarsus v $2-0-0, \mathrm{r} 0-1-1, \mathrm{~d} 0-1-2, \mathrm{p} 1-1-1$; tibia v 1-3-2, p 0-1-1; patella p 0-1-0; femur d 0-2-3. Epigyne (Fig. 12D): clothed in dark grey hairs.

Dimensions $(\mathrm{mm})$ : total length $4 \cdot 44$; carapace length $2 \cdot 0$, breadth $1 \cdot 68$, height $1 \cdot 32$; abdomen length $2 \cdot 32$; eyes, anterior row $1 \cdot 72$, middle row $1 \cdot 38$, posterior row $1 \cdot 61$; quadrangle length $1 \cdot 12$ (56\% of carapace length).

\begin{tabular}{lccccc} 
Leg & 1 & 2 & 3 & 4 & Palp \\
Femur & 1.52 & 1.36 & 1.36 & 1.76 & 0.76 \\
Patella & 0.78 & 0.68 & 0.62 & 0.68 & 0.40 \\
Tibia & 1.12 & 0.96 & 1.00 & 1.40 & 0.52 \\
Metatarsus & 1.02 & 0.96 & 1.11 & 1.56 & - \\
Tarsus & 0.56 & 0.56 & 0.58 & 0.70 & 0.66 \\
\hline Total & 5.00 & 4.52 & 4.67 & 6.10 & 2.34
\end{tabular}

Ratios: AM : AL : PM : PL :: $14: 8: 4: 8 ; \mathrm{AL}-\mathrm{PM}-\mathrm{PL}:: 7-7 \cdot 5 ; \mathrm{AM}: \mathrm{CL}:: 14: 3$.

MaLe PaRATYPe, abdomen and legs IV missing, otherwise in fair condition. Similar to female except for the following. Carapace (Fig. 12E): heavily suffused and mottled black especially on sides; rubbed except for shining violet hairs behind anterior eyes. Clypeus: with scattered fine whitish hairs. Chelicerae: yellow-brown with sooty markings, shiny, clothed in scattered black hairs with dense promarginal scopulae; promargin with five teeth retromargin with seven denticles (Fig. 12C). Spination of leg I: metatarsus v 2-2-2, r 1-0-0, d 0-2-2, p 1-0-0; tibia v 1-3-2, p 0-1-1, r 1-0-1, d 1-0-0; patella p 0-1-0, r 0-1-0; femur d 0-2-3. Palp (Fig. 12G, H, J): femur and patella pale yellowish lightly suffused black; tibia and cymbium light to dark amber mottled with some black; clothed in brownish hairs with patch of white hairs on patella and apices of femora.

Dimensions $(\mathrm{mm})$ : total length ?; carapace length 1.92 , breadth $1 \cdot 22$, height $1 \cdot 32$; abdomen length ?; eyes, anterior row $1 \cdot 64$, middle row $1 \cdot 29$, posterior row $1 \cdot 52$; quadrangle length $1 \cdot 12(58 \%$ of carapace length).

\begin{tabular}{lccccc} 
Leg & 1 & 2 & 3 & 4 & Palp \\
Femur & 1.58 & 1.44 & 1.40 & - & 0.80 \\
Patella & 0.76 & 0.68 & 0.60 & - & 0.36 \\
Tibia & 1.26 & 1.04 & 1.08 & - & 0.46 \\
Metatarsus & 1.16 & 1.08 & 1.22 & - & - \\
Tarsus & 0.62 & 0.60 & 0.64 & - & 0.92 \\
\hline Total & 5.38 & 4.84 & 4.94 & - & 2.54
\end{tabular}

Ratios: AM : AL : PM : PL :: $14: 8: 4: 8 ;$ AL—PM-PL :: 6-7; AM : CL :: 14 : 5.

DisTRIBUTION. Sumatra.

Material eXamined. Sumatra, Bohorok, Gunung Leuser Reserve: holotype + , in litter, 14.vi. 1983, P. $R$. Deeleman and C. L. Deeleman-Reinhold; paratype ${ }^{2}$, in bamboo litter on plateau with large bamboo trees, $50 \mathrm{~m}, 10$ ii.1983, P. R. Deeleman and S. Djojosudharma (Rijksmuseum van Natuurlijke Histoire, Leiden).

ETYMOLOGY. The specific name refers to the country in which the holotype was collected. 



Fig. 13. Taraxella reinholdae sp. n., holotype $\delta$ : A, dorsal view; B, carapace, lateral view; C, leg I; D, palpal tibia, dorsal view; E, cheliceral teeth; F, palp, ventral view; G, palp, retrolateral view. Abbreviations: M1, fan-shaped element of distal haematodocha; tf, tegular furrow; va, ventral apophysis; ' $\mathrm{x}$ ' and 'y', tegular apophyses.

Taraxella reinholdae sp. $\mathrm{n}$.

(Fig. 13A-G)

DiAGNOSIs. Easily separated from other species of Taraxella by the conspicuous tuft of stout setae arising from the retrolateral surface of the palpal tibial apophysis (Fig. 13D, F, G).

Female. Unknown.

MALE HOLOTYPE in fair condition. Carapace (Fig. 13A, B): mottled black with metallic sheen and pale yellowish green markings on thoracic part; irregularly clothed, in scattered black and white hairs with a central white haired stripe behind anterior median eyes. Eyes: laterals with black surrounds; fringed by white hairs with scattered dark grey hairs around laterals and upper rims of anterior medians. Clypeus: clothed in scattered white hairs. Chelicerae: black with metallic sheen except for light greyish amber inner margins; sparsely clothed in light greyish hairs with moderately dense promarginal scopulae; promargin with five teeth, retromargin with seven denticles (Fig. 13E). Maxillae and labium: pale yellow-brown heavily mottled black with whitish inner distal 
margins on maxillae and labial tip. Sternum: yellow-brown suffused black; shiny, with scattered fine blackish hairs. Coxae: pale greyish yellow suffused with some black. Abdomen: dorsum and sides yellowish green heavily tinged black; clothed in brown-black hairs with vague patches of whitish hairs laterally; venter pale yellow with black surrounds, clothed in grey black hairs; spinnerets black with blackish hairs. Legs (Fig. 13C): moderately long and slender; generally black except for pale yellowish brown tarsi and yellow-brown annuli on metatarsi, tibiae and patellae; spines strong and numerous. Spination of leg I: metatarsus v $2-0-0, p 1-0-2$, d 1-1-2; tibia v 2-2-2, p 1-0-1, d 1-1-0; patella p 0-1-0, r 0-1-0; femur d 0-2-3. Palp (Fig. 13D, F, G): patella pale yellow tinged with some black, other segments heavily mottled black; clothed in black hairs with patch of whitish hairs on patella and apices of femora.

Dimensions $(\mathrm{mm})$ : total length ca. $3 \cdot 2$ (bent); carapace length $1 \cdot 52$, breadth $1 \cdot 44$, height $1 \cdot 16$; abdomen length $1 \cdot 68$; eyes, anterior row $1 \cdot 48$, middle row $1 \cdot 16$, posterior row $1 \cdot 40$; quadrangle length $1 \cdot 0$ (65\% of carapace length).

\begin{tabular}{lccccc} 
Leg & 1 & 2 & 3 & 4 & Palp \\
Femur & 1.28 & 1.18 & 1.20 & 1.56 & 0.64 \\
Patella & 0.66 & 0.58 & 0.54 & 0.60 & 0.32 \\
Tibia & 1.02 & 0.84 & 0.88 & 1.20 & 0.32 \\
Metatarsus & 0.96 & 0.88 & 0.96 & 1.42 & - \\
Tarsus & 0.52 & 0.48 & 0.52 & 0.61 & 0.72 \\
\hline Total & 4.44 & 3.96 & 4.10 & 5.39 & 2.00
\end{tabular}

Ratios: AM : AL : PM : PL :: $7: 12 \cdot 5: 2: 7$; AL—PM—PL :: 8-7; AM : CL :: $12 \cdot 5: 3 \cdot 5$.

Distribution. Borneo, Sarawak.

MAterial eXAmined. Sarawak: Bako National Park, holotype $\widehat{\jmath}$, in litter, in swampy forest, 29-30.iii.1985. C. L. Deeleman-Reinhold and P. R. Deeleman, (RNH, Leiden).

ETYMology. This species is named for one of the collectors Dr C. L. Deeleman-Reinhold.

\section{Acknowledgements}

I would like to thank Dr C. L. Deeleman-Reinhold, Ossendrecht, Holland and Dr P. Lehtinen, University of Turku, Turku, Finland for allowing me to study their collections of oriental salticids.

I am also indebted to my colleague Mr P. D. Hillyard for collecting spiders in Indonesia and Malaysia and for providing photographs for Figs 1-2. Mrs F. Murphy, London kindly supplied the photograph for Figure 3.

Finally I would like to thank Dr R. R. Jackson, University of Canterbury, Christchurch, New Zealand and Mr D. Macfarlane, Commonwealth Institute for Entomology, London for reading the manuscript.

\section{References}

Blest, A. D. 1984. Secondary retinae of a primitive jumping spider, Yaginumanis (Arachnida, Araneida, Salticidae). Zoomorphology 104: 223-225.

- 1985. V. The fine structure of spider photoreceptors in relation to function. In: F. C. Barth, Ed., Neurobiology of Arachnids. Springer-Verlag, Berlin.

— \& Sigmund, C. 1985. Retinal mosaics of a primitive jumping spider, Spartaeus (Salticidae: Araneae): A transition between principal retinae serving low and high spatial acuities. Protoplasma 125: 129-139.

Coleman, N. C. 1978. A spider aberration-Linus fimbriatus. N. Qd. Nat. 44: 5.

1980. Web construction by Portia - a spider of the family Salticidae, commonly known as jumping spiders. N. Qd. Nat. 45; 7-8.

Hill, D. E. 1977. Pores in the integument. Peckhamia 1(1): 9.

Homann, H. 1971. Die Augen der Araneae. Anatomie, Ontogenie und Bedeutung fur die Systematik (Chelicerata, Arachnida). Z. Morph. Tiere. 69: 201-272. 
Jackson, R. R. 1979. Nests of Phidippus johnsoni (Araneae, Salticidae): characteristics, pattern of occupation, and function. J. Arachnol. 7: 47-58.

1982. The biology of Portia fimbriata, a web-building jumping spider (Araneae, Salticidae) from Queensland: intraspecific interactions. J. Zool., Lond. 196: 295-305.

- 1985a. The biology of Simaetha paetula and S. thoracica web-building jumping spiders (Araneae, Salticidae) from Queensland: co-habitation with social spiders, utilization of silk, predatory behaviour and intraspecific interactions. J. Zool. Lond. (B) 1(1): 175-210.

- 1985b. Web-building, predatory versatility and the evolution of the Salticidae. In: W. A. Shear, Ed., The evolution of spiders webs. Stanford University Press.

- (in press). Communal jumping spiders (Araneae: Salticidae) from Kenya: interspecific nest complexes, co-habitation with web-building spiders, and intraspecific interactions. N.Z. J. Zool.

\& Blest, A. D. 1982. The biology of Portia fimbriata, a web-building jumping spider (Araneae, Salticidae) from Queensland: utilization of webs and predatory versatility. J. Zool. Lond. 196: 255-293.

\& Hallas, S. E. A. (in press $a$ ). Comparative biology of Portia africana, P. albimana, P. fimbriata, $P$. labiata and $P$. schultzi, araneophagic web-building jumping spiders (Araneae, Salticidae): utilization of webs, predatory versatility, and intraspecific interactions. N.Z. Jl. Zool.

$-\&-$ in press $b$ ). Predatory versatility and intraspecific interactions of spartaeine jumping spiders (Araneae: Salticidae): Brettus adonis, B. cingulatus, Cyrba algerina, and Phaeacius sp. n. N.Z. Jl. Zool.

Legendre, R. \& Llinares, D. 1970. L'accouplement de l'araignée salticide Cyrba algerina (Lucas, 1846). Annls Soc. Hort. Hist. nat. Herault 110(4): 169-174.

Loerbroks, A. L. 1984. Mechanik der Kopulationsorgane von Misumena vatia (Clerck, 1757) (Arachnida: araneae: Thomisidae). Verh. naturwisc. Ver. Hamburg (NF) 27: 383-403.

Platnick, N. I. \& Shadab, M. U. 1975. A revision of the spider genus Gnaphosa (Araneae: Gnaphosidae) in America. Bull. Am. Mus. nat. Hist. 155: 3-66.

Wanless, F. R. 1978a. A revision of the spider genera Belippo and Myrmarachne (Araneae: Salticidae) in the Ethiopian Region. Bull. Br. Mus. nat. Hist. (Zool.) 33(1): 139 pp.

1978b. A revision of the spider genus Portia (Araneae: Salticidae). Bull. Br. Mus. nat. Hist. (Zool.) 34(3): 83-124.

- 1984a. A review of the spider subfamily Spartaeinae nom. n. (Araneae: Salticidae) with descriptions of six new genera. Bull. Br. Mus. nat. Hist. (Zool.) 46(2): 135-205.

1984b. A revision of the spider genus Cyrba (Araneae: Salticidae) with the description of a new presumptive pheromone dispersing organ. Bull. Br. Mus. nat. Hist. (Zool.) 47(7): 445-481.

- 1985. A revision of the spider genera Holcolaetis and Sonoita (Araneae: Salticidae). Bull. Br. Mus. nat. Hist. (Zool.) 48(4): 249-278. 

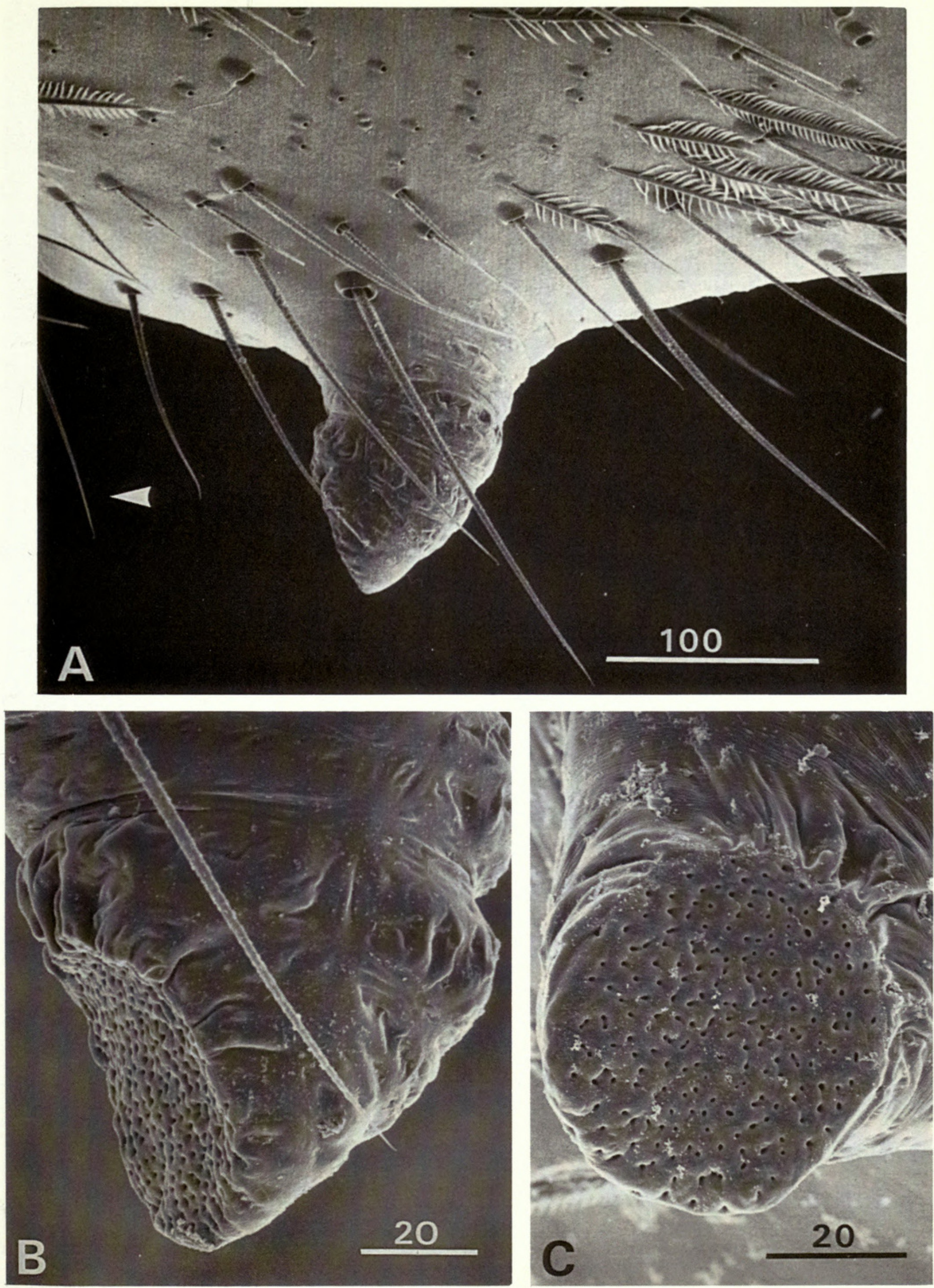

Fig. 14. Spartaeus wildtrackii sp. n., paratype $\widehat{乛}$ : femoral organ: A, $\times 316 ; \mathrm{B}, \times 820 ; \mathrm{C}, \times 1040$. Scale bars $\mu \mathrm{m}$. Arrow indicates direction of coxa. 

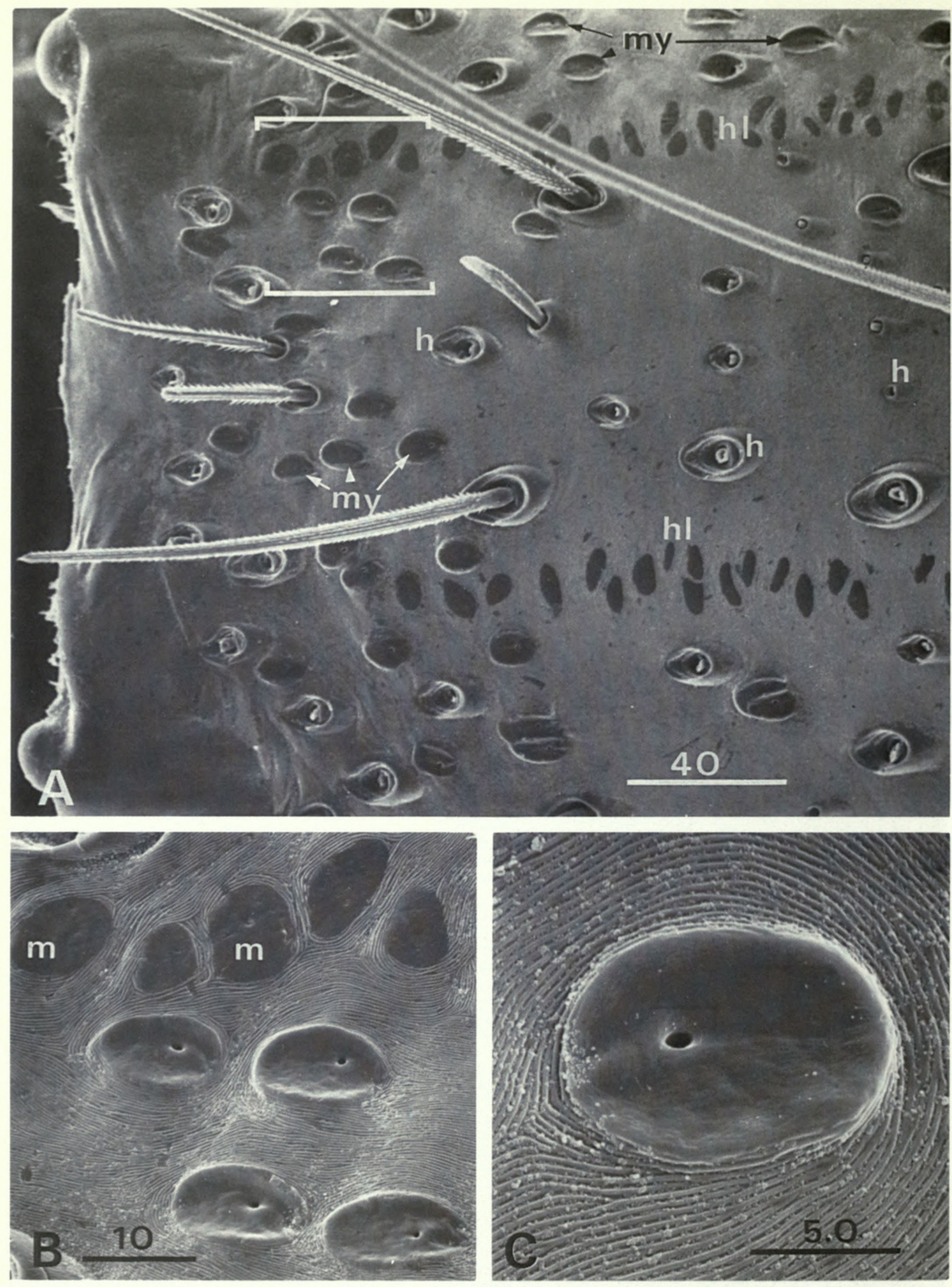

Fig. 15. Spartaeus wildtrackii sp. n., §ै, tibia II: A, dorsal view of distal region showing distribution of mytiliform organs and muscle attachment sites, $\times 570$; B, mytiliform organs and muscle attachment sites, $\times 1600$; C, detail of mytiliform organ, $\times 4200$. Abbreviations: $h$, hair sockets; hl, hinge line; $m$, muscle attachment site; my, mytiliform organ. Scale bars $\mu \mathrm{m}$. 

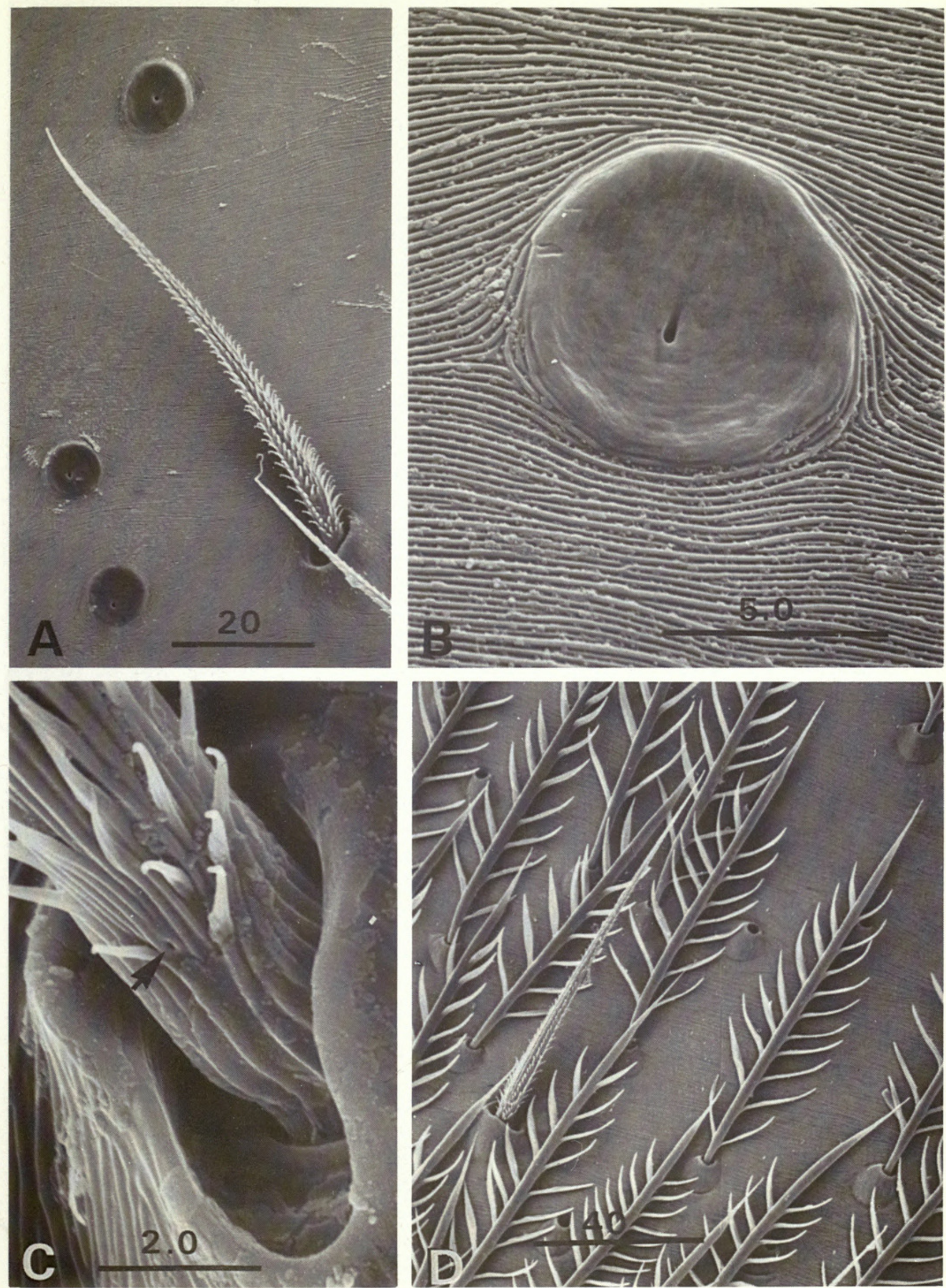

Fig. 16. Spartaeus wildtrackii sp. n., ỡ: A, femora I, mytiliform organs and seta, $\times 1000$; B, femora II, detail of mytiliform organ, $\times 6200 ; \mathrm{C}$, metatarsus II, base of filimentous seta showing dendritic pore, $\times 10300 ; \mathrm{D}$, femora I, feathery setae, $\times 620$. Scale bars $\mu \mathrm{m}$. 

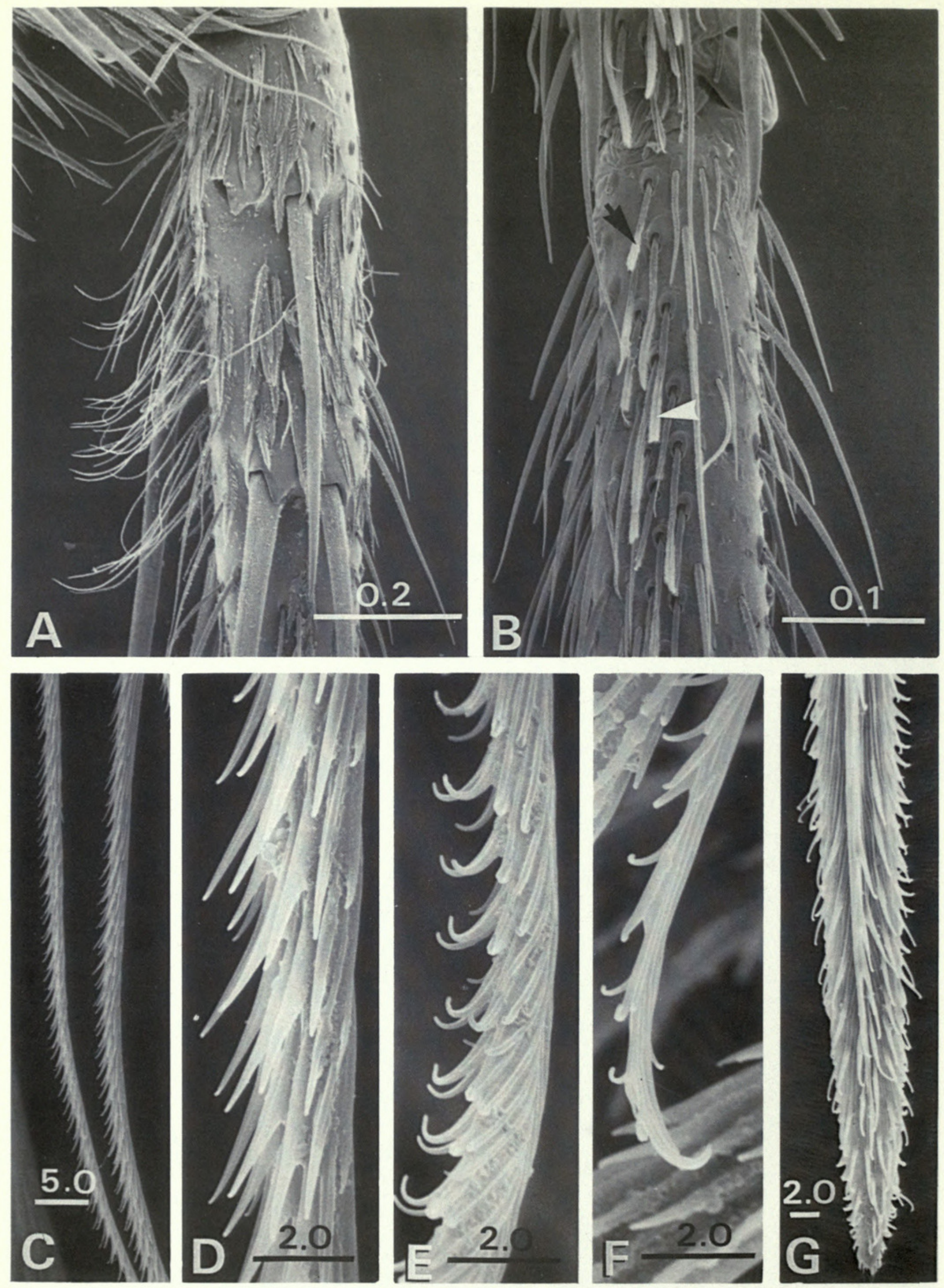

Fig. 17. Spartaeus wildtrackii, sp. n., ơ: A, basal half of metatarsi II, lateral view showing fringe of filamentous setae; C, two filamentous setae, $\times 1300$; D, E, F, mid region, distal region and tip of filamentous setae, $\times 7000, \times 8000, \times 8000$; $\mathrm{B}$, basal half of tarsi II, ventral view showing row of prey capture setae, arrowed; $\times 210 ; \mathrm{G}$, detail of prey capture setae, $\times 2000$. Scale bars $\mu \mathrm{m}$. 

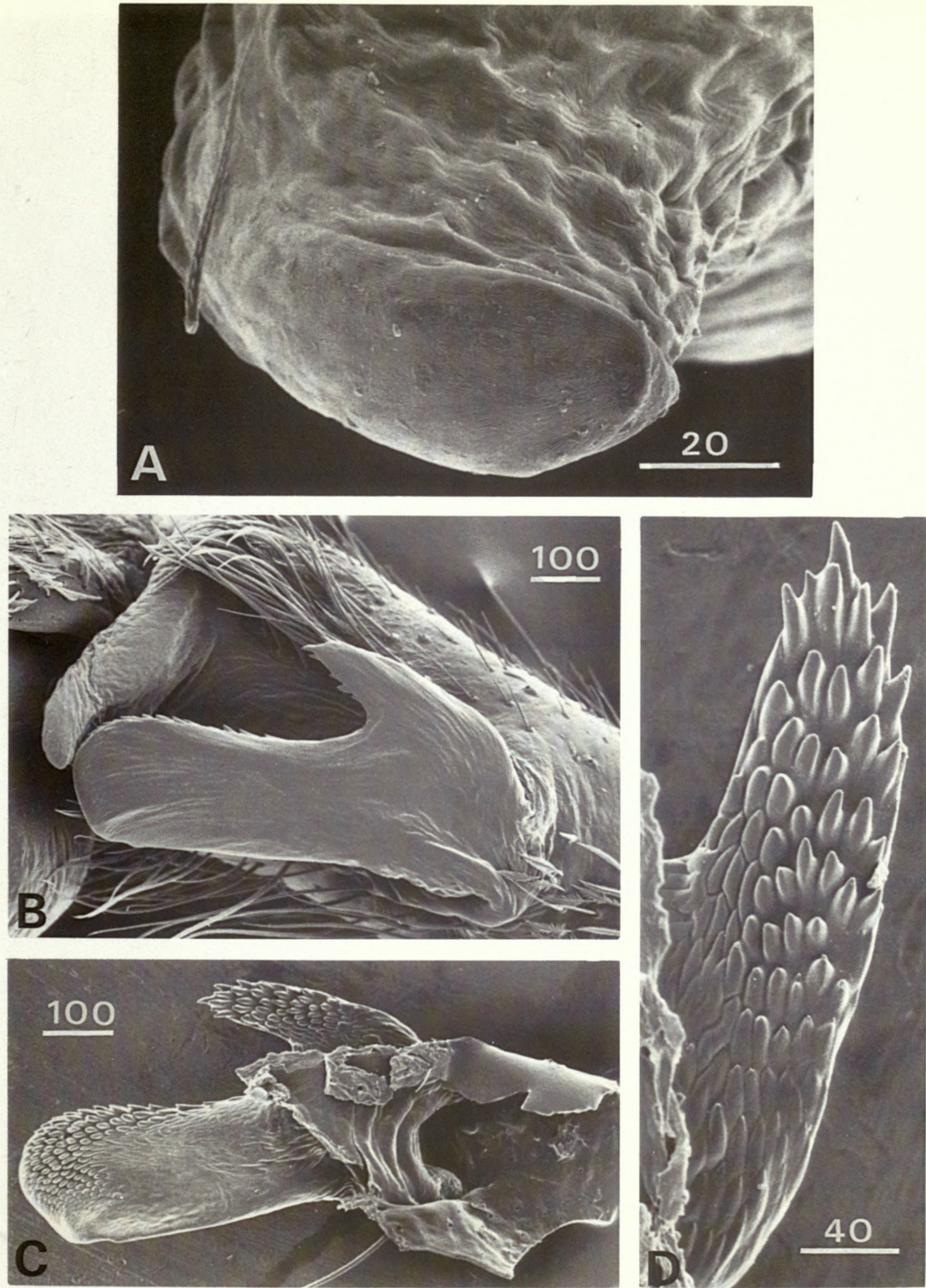

Fig. 18. Spartaeus wildtrackii sp. n., tibia of male palpal organ: A, ventral apophysis inner view, $\times 1000$; $\mathrm{B}$, retrolateral apophysis, outer view, $\times 100$; , retrolateral apophysis, inner view, $\times 100$; $\mathrm{D}$, detail of dorsal prong of retrolateral apophysis, $\times 350$. Scale bars $\mu \mathrm{m}$. 

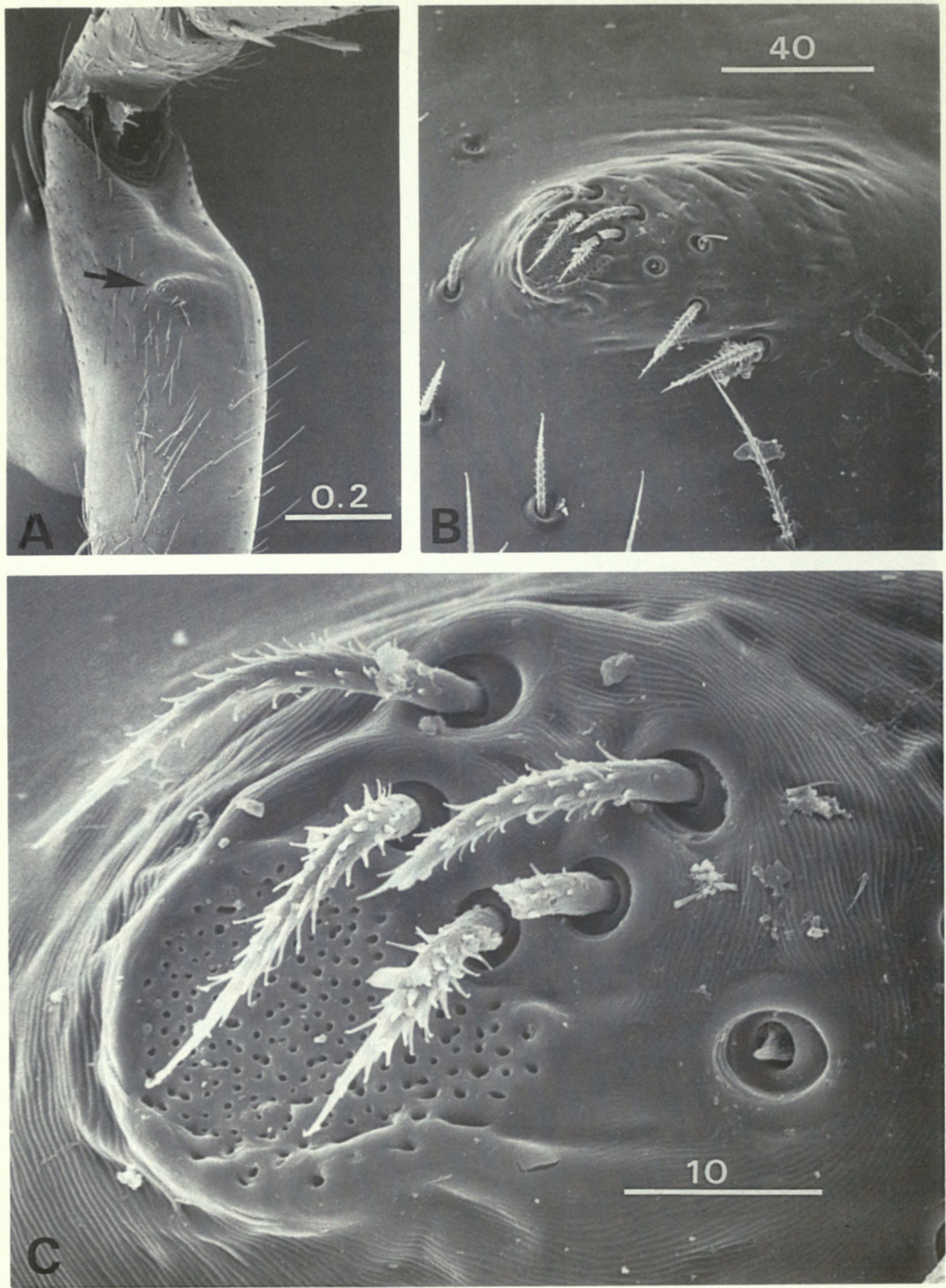

Fig. 19. Mintonia caliginosa sp. n., o : A, underside of femora I showing position of femoral organ, arrowed, $\times 75$; B, femoral organ, $\times 550$; , femoral organ showing pores, $\times 2800$. Scale bars $\mathrm{A}, \mathrm{mm}$; $\mathrm{B}, \mathrm{C}, \mu \mathrm{m}$. 

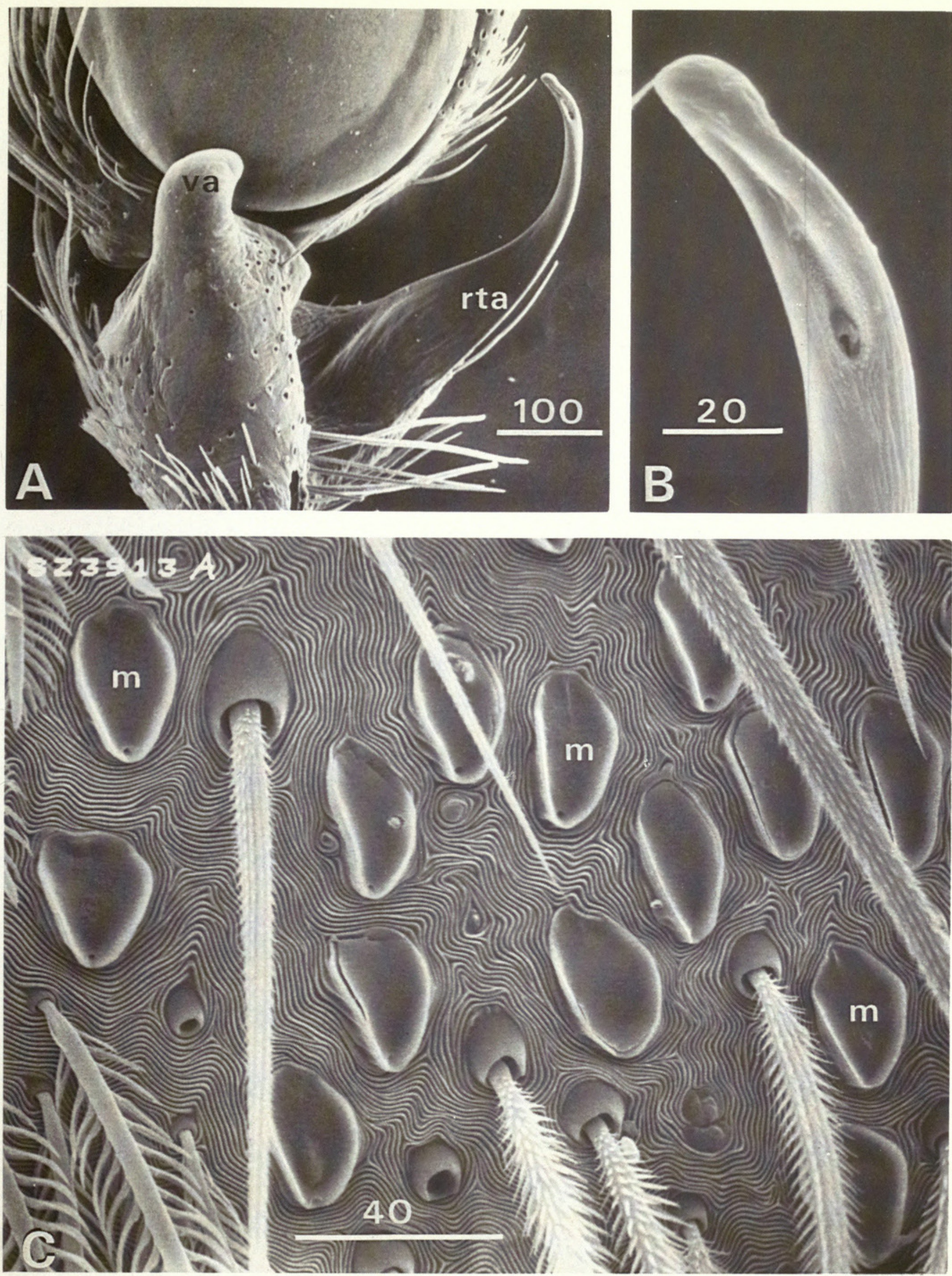

Fig. 20. (A, B) Mintonia tauricornis Wanless, ô, palpal organ: A, tibia showing ventral apophysis and pore bearing retrolateral apophysis, $\times 150 ; \mathrm{B}$, tip of retrolateral apophysis showing pore, $\times 850$. C, Portia labiata Thorell, $\sigma^{*}$, showing mytiliform field on dorsal surface of abdomen, $\times 730$. Abbreviations: m, mytiliform organs; va, ventral apophysis; rta, retrolateral tibial apophysis. Scale bars $\mu \mathrm{m}$. 


\section{$2 \mathrm{BHL}$ Biodiversity Heritage Library}

Wanless, F. R. 1987. "Notes on spiders of the family Salticidae. 1. The genera Spartaeus, Mintonia and Taraxella." Bulletin of the British Museum (Natural History) Zoology 52, 107-137. https://doi.org/10.5962/p.18302.

View This Item Online: https://www.biodiversitylibrary.org/item/19520

DOI: https://doi.org/10.5962/p.18302

Permalink: https://www.biodiversitylibrary.org/partpdf/18302

\section{Holding Institution}

Natural History Museum Library, London

\section{Sponsored by}

Natural History Museum Library, London

\section{Copyright \& Reuse}

Copyright Status: In copyright. Digitized with the permission of the rights holder.

Rights Holder: The Trustees of the Natural History Museum, London

License: http://creativecommons.org/licenses/by-nc-sa/4.0/

Rights: http://biodiversitylibrary.org/permissions

This document was created from content at the Biodiversity Heritage Library, the world's largest open access digital library for biodiversity literature and archives. Visit BHL at https://www.biodiversitylibrary.org. 